\title{
Pd-Ir alloy as an anode material for borohydride oxidation
}

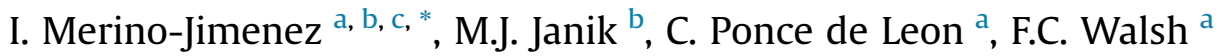 \\ a Electrochemical Engineering Laboratory, Energy Technology Research Group, Engineering Sciences, University of Southampton, Highfield Rd., \\ Southampton SO17 1BJ, UK \\ ${ }^{\mathrm{b}}$ Department of Chemical Engineering, Pennsylvania State University, University Park, PA 16802, USA \\ c Bristol Robotics Laboratory, Universities of Bristol and of the West of England, Bristol Business Park, Coldharbour Lane, BS16 1QY, UK
}

\section{H I G H L I G H T S}

- Pd-Ir shows high catalytic activity towards the $\mathrm{NaBH}_{4}$ oxidation.

- Low $\mathrm{H}_{2}$ generation $\left(<0.1 \mathrm{dm}^{3} \mathrm{~min}^{-1}\right)$ at potentials more positive than the OCP.

- The mechanism of $\mathrm{NaBH}_{4}$ oxidation on Pd-Ir alloys was computationally elucidated.

- Experimental and DFT studies agree on the $\mathrm{H}_{2}$ generation at the OCP.

\section{A R T I C L E I N F O}

\section{Article history:}

Received 16 April 2014

Received in revised form

31 May 2014

Accepted 25 June 2014

Available online 7 July 2014

\section{Keywords:}

Borohydride oxidation

DBFC

Hydrolysis of borohydride

DFT

Electrocatalysis

\begin{abstract}
A B S T R A C T
A Pd-Ir alloy (1:1) coated on microfibrous carbon (11 $\mu \mathrm{m}$ diameter) supported on a titanium plate was evaluated as an electrode for the anodic oxidation of borohydride. The hydrogen generated, due to the parallel reaction of borohydride hydrolysis, was measured during the electrolysis obtaining less than $0.1 \mathrm{~cm}^{3} \mathrm{~min}^{-1} \mathrm{H}_{2}$ between -1 and $0 \mathrm{~V} v \mathrm{~s}$. $\mathrm{Hg} / \mathrm{HgO}(-0.86$ and $0.14 \mathrm{~V} v$ s. SHE), while the current densities for the oxidation of borohydride were up to $367 \mathrm{~mA} \mathrm{~cm}^{-2}$ in $0.5 \mathrm{~mol} \mathrm{dm}^{-3} \mathrm{NaBH}_{4}+3 \mathrm{~mol} \mathrm{dm}^{-3} \mathrm{NaOH}$. The low rate of hydrogen generation suggests that $\mathrm{Pd}-\mathrm{Ir}$ could be a promising catalyst for borohydride oxidation. However, higher rates of hydrogen were generated at the open circuit potential, which is inconvenient in the direct borohydride fuel cell. Cyclic voltammetry allowed analysis of the oxidation peaks due to the borohydride oxidation. To obtain a further understanding of the borohydride oxidation mechanism at Pd-Ir electrodes, density functional theory (DFT) was used to examine the reaction mechanism at $\mathrm{Pd}_{2}-\mathrm{Ir}_{1}(111)$ and $\mathrm{Pd}_{2}-\mathrm{Ir}_{2}(111)$ surfaces. The competition between borohydride oxidation and hydrogen evolution on the Pd-Ir alloys is compared with that on pure $\mathrm{Pd}(111)$, suggesting that the presence of Ir favors borohydride oxidation rather than hydrogen evolution.
\end{abstract}

() 2014 Elsevier B.V. All rights reserved.

\section{Introduction}

Sodium borohydride has been proposed as an alternative fuel for fuel cells as it presents many advantages in comparison with other fuels: it is safer and easier to transport than hydrogen gas, the oxidation products (metaborates and water) are environmentally friendly, and the theoretical specific energy density of the direct borohydride fuel cell (DBFC) is larger than other systems, $9.3 \mathrm{~kW} \mathrm{~h} \mathrm{~kg}^{-1}$. However, there are still major issues that need to be resolved if the DBFC is going to advance in application. These

\footnotetext{
* Corresponding author. Electrochemical Engineering Laboratory, Energy Technology Research Group, Engineering Sciences, University of Southampton, Highfield Rd., Southampton SO17 1BJ, UK.

E-mail address: Irene.Merinojimenez@uwe.ac.uk (I. Merino-Jimenez).
}

include the lack of a selective catalyst with high activity for direct borohydride oxidation, a reliable anionic membrane, the instability of borohydride and avoidance of its hydrolysis. These aspects limit the fuel cell efficiency to less than $30 \%[1,2]$ of the theoretical available energy.

Sodium borohydride is highly soluble in alkaline solution and is oxidized at the anode through the following Reaction (1):

$$
\begin{aligned}
& \mathrm{BH}_{4, \mathrm{aq}}^{-}+8 \mathrm{OH}_{\mathrm{aq}}^{-} \rightarrow \mathrm{BO}_{2, \mathrm{aq}}^{-}+6 \mathrm{H}_{2} \mathrm{O}_{\mathrm{aq}}+8 e^{-} \\
& E^{o}=-1.24 \mathrm{~V} v \text { s. SHE }
\end{aligned}
$$

However, a parallel hydrolysis Reaction (2) decreases the overall number of electrons released per borohydride molecule to less than 8 , decreasing the power density and producing hydrogen gas in the anolyte: 
$\mathrm{BH}_{4, \mathrm{aq}}^{-}+2 \mathrm{H}_{2} \mathrm{O}_{\mathrm{aq}} \rightarrow \mathrm{BO}_{2, \mathrm{aq}}^{-}+4 \mathrm{H}_{2}$

Although the hydrogen produced could be oxidized, the overall energy output will be lower. Hydrogen bubbles can also block the electrode surface and should be minimized to avoid safety issues. The overall Reaction (3) is the result of combining Reactions (1) and (2):

$\mathrm{BH}_{4}^{-}+x \mathrm{OH}^{-} \rightarrow \mathrm{BO}_{2}^{-}+(x-2) \mathrm{H}_{2} \mathrm{O}+(4-(1 / 2) x) \mathrm{H}_{2}+x e^{-}$

where $x$ is the number of electrons released per borohydride ion [3].

Several catalysts have been studied for the direct oxidation of borohydride ions. Gold and silver have been reported to have good selectivity, extracting an equivalent 8 or almost 8 electrons during oxidation [4-6]. However, Chatenet et al., [7] claimed that the hydrogen generation rate during the borohydride oxidation at a gold electrode is not negligible and that at high potentials ( $>0.3-0.5 \mathrm{~V} v s$. SHE) the number of electrons released per borohydride molecule is less than 8 . Catalysts such as Pt, Pd and Ni also catalyze both oxidation and hydrolysis reactions, releasing between 3 and 6 electrons per borohydride converted [2,3,8-10]. The highest power density reported for a DBFC, $1.44 \mathrm{~W} \mathrm{~cm}^{-2}$, was obtained using a $25 \mathrm{~cm}^{2} \mathrm{NaBH}_{4} / \mathrm{H}_{2} \mathrm{O}_{2}$ single cell with a $\mathrm{Pd} / \mathrm{C}$ anode and an $\mathrm{Au} / \mathrm{C}$ cathode separated by a Nafion 112 membrane [11]. The authors reported that the effective number of electrons released on a Pd electrode was less than 8 (between 4 and 6 depending on the $\mathrm{NaBH}_{4}$ concentration) [3,12]. Despite not providing the full 8 electrons, Pd catalysts lead to large current densities and charge efficiencies [3,12].

Although Pd-based alloys have not been tested, alloying electrodes such as Pt, Ag or Au with other materials has improved the performance of the DBFC. Gyenge et al., [8] obtained higher peak currents and more negative borohydride oxidation potentials by using a Pt-Au alloy instead of pure Pt. Alloys such as Pt-Ir and $\mathrm{Pt}-\mathrm{Ni}$ were also tested as working electrodes for a DBFC [8]. The anolyte solutions contained $2 \mathrm{~mol} \mathrm{dm}{ }^{-3} \mathrm{NaBH}_{4}$ in $2 \mathrm{~mol} \mathrm{dm} \mathrm{dm}^{-3}$ $\mathrm{NaOH}$, a $5 \mathrm{mg} \mathrm{cm}^{-2} \mathrm{Pt}-\mathrm{Ir}$ and Pt-Ni loading, a Nafion 117 membrane, and an $\mathrm{O}_{2}$ gas diffusion cathode with $4 \mathrm{mg} \mathrm{cm}^{-2} \mathrm{Pt}$. The use of $\mathrm{Pt}-\mathrm{Ir}$ and $\mathrm{Pt}-\mathrm{Ni}$ catalysts gave the same power density of $53 \mathrm{~mW} \mathrm{~cm}{ }^{-2}$ at $75{ }^{\circ} \mathrm{C}$, showing the most active catalytic activity among all the catalyst being tested. When Pt-Ir was used, the oxidation peaks were shifted to more negative potentials than those observed with $\mathrm{Pt}-\mathrm{Ni}$, suggesting the potentially favorable kinetics on Pt-Ir alloy and yielding the highest voltammetric $\mathrm{BH}_{4}^{-}$ oxidation current densities [8]. Kiran et al., [13] increased the power density of a DBFC by 35\% by using an Ir-Rh alloy supported on carbon compared to a carbon supported Rh anode.

It might be possible to increase the activity of pure Pd by alloying it with Ir, as it was observed by Gyenge et al., [8] and Kiran et al., [13] for the addition of Ir to Pt and Rh to form Pt-Ir and Rh-Ir alloys, respectively. In this work, cyclic voltammetry was performed to analyze the oxidation peaks and current densities of borohydride oxidation on a Pd-Ir alloy anode. Also the hydrogen generation rate was measured during the potentiostatic electrolysis of a borohydride alkaline solution at constant potential. In order to corroborate the experimental work and obtain a better understanding of the reaction mechanism of the borohydride ions at the Pd-Ir(111) surface, DFT calculations have been used and the preferred reaction path is presented. DFT methods have previously been used to evaluate the borohydride oxidation mechanism on $\mathrm{Au}(111), \mathrm{Pt}(111)$ and $\mathrm{Au}_{2} \mathrm{Cu}_{1}$ (111) surfaces [14-16]. The analysis of the $\mathrm{Pd}-\operatorname{Ir}(111)$ elementary surface reaction energetics through DFT calculations can help to corroborate the selectivity of Pd-Ir alloys towards the oxidation of borohydride. The linear free energy, computational hydrogen electrode method is used to determine potential dependent reaction energies [17]. Potential dependent activation barriers for elementary reaction steps are determined using an approach recently developed in the Janik group $[16,18]$. The effect of the Ir content of in the Pd-Ir alloy is also analyzed by considering reaction energetics on $\operatorname{Pd}_{2} \operatorname{Ir}_{1}(111)$ and $\operatorname{Pd}_{2} \operatorname{Ir}_{2}(111)$ surfaces.

\section{Experimental details}

The electrode material consisted of Pd-Ir nanoparticles deposited on carbon microfibres of $11 \mu \mathrm{m}$ diameter and supported on a planar titanium foil substrate. The microfibrous carbon catalyst support was obtained by a direct charging electrostatic flocking technique and was provided by Dr. C. Patrissi from the Naval Under Sea Water Fare Centre [19]. The electrode was manufactured by applying a $30-100 \mathrm{kV}$ pulse between a carbon plate, containing the $0.5 \mathrm{~mm}$ length and $10 \mu \mathrm{m}$ diameter carbon microfibres (Mitsubishi Chemical K637212), and the titanium foil substrate plate contained a carbon adhesive film [19]. The density of the carbon microfibres on the titanium foil was around 12,5000 fibers per $\mathrm{cm}^{-2}$. Fig. 1 shows SEM images of the carbon fibers on Ti, a) before and b) after the Pd-Ir catalyst coating. A catalyst loading of $12.3 \mathrm{mg} \mathrm{cm}^{-2}$, with a composition of 50:50 Pd:Ir, was obtained by linearly cycling the electrode with the carbon microfibres in a solution containing $2 \times 10^{-3} \mathrm{~mol} \mathrm{dm}^{-3} \mathrm{PdCl}_{2}$ and $2 \times 10^{-3} \mathrm{~mol} \mathrm{dm}^{-3} \mathrm{Na}_{2} \mathrm{IrCl}_{6} \mathrm{H}_{2} \mathrm{O}$ in $0.2 \mathrm{~mol} \mathrm{dm}^{-3} \mathrm{KCl}$ and $0.1 \mathrm{~mol} \mathrm{dm}{ }^{-3} \mathrm{HCl}$ at $70{ }^{\circ} \mathrm{C}$. Cyclic voltammetry was carried out at $1 \mathrm{mV} \mathrm{s}^{-1}$ between $-0.15 \mathrm{~V}$ and $-0.3 \mathrm{~V} v \mathrm{~s}$. $\mathrm{Ag} / \mathrm{AgCl}[19]$.

Potentiostatic electrolysis at a constant potential were carried out between -0.8 and $0.4 \mathrm{~V} v$ s. $\mathrm{Hg} / \mathrm{HgO}(-0.66$ and $0.54 \mathrm{~V} v$ s. SHE) in order to measure the hydrogen generation rate at the microfibrous Pd-Ir electrode. The accumulative hydrogen gas generated from the borohydride hydrolysis and the current densities during the electrolysis were monitored. A computer controlled potentiostat/galvanostat PGSTAT30 from Autolab (EcoChemie, Netherlands) fitted with the General Purpose Electrochemical System GPES 4.9 software was used to apply the constant potential. A three electrode glass cell was used during the electrolysis experiments with the working ( $3 \mathrm{~cm}^{2}$ geometric area) and counter electrode compartments separated with a Nafion 117 ion exchange membrane. The counter electrode compartment was filled with a solution of $3 \mathrm{~mol} \mathrm{dm}^{-3} \mathrm{NaOH}$ while the working electrode compartment was gas tight and connected to an inverted $50 \mathrm{~cm}^{3}$ burette in order to measure the amount of hydrogen gas generated during borohydride oxidation. The working electrode compartment was filled with solutions containing $3 \mathrm{~mol} \mathrm{dm}{ }^{-3} \mathrm{NaOH}$ and two $\mathrm{NaBH}_{4}$ concentrations: $0.5 \mathrm{~mol} \mathrm{dm}{ }^{-3}$ or $1 \mathrm{~mol} \mathrm{dm}^{-3}$. The cyclic voltammetry experiments were carried out at $10 \mathrm{mV} \mathrm{s}^{-1}$ at lower concentrations of borohydride $0.02 \mathrm{~mol} \mathrm{dm}^{-3}$ in $3 \mathrm{~mol} \mathrm{dm}^{-3} \mathrm{NaOH}$ in a cell with a smaller Pd-Ir electrode of $0.283 \mathrm{~cm}^{2}(0.6 \mathrm{~cm}$ diameter $)$ geometrical

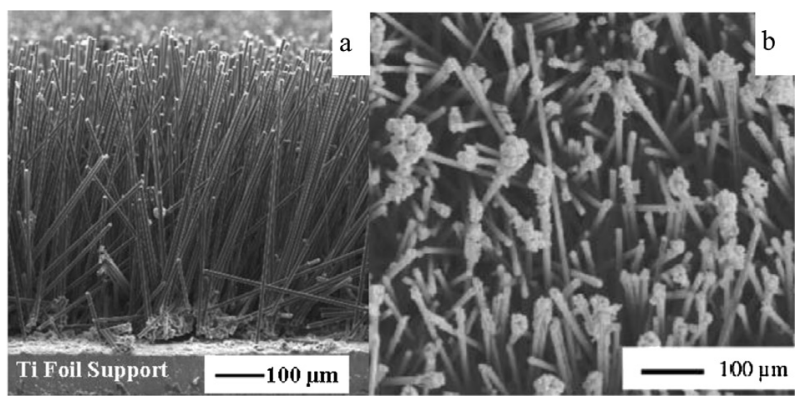

Fig. 1. SEM image of a) carbon fibers deposited by direct charging electrostatic flocking. b) Pd-Ir coated carbon microfibre array [19]. 
area. Both cells used a Pt mesh $\left(2 \mathrm{~cm}^{2}\right)$ as counter electrode, separated by a Nafion 117 proton membrane, and a $\mathrm{Hg} / \mathrm{HgO}$ reference electrode.

\section{Results and discussion}

Fig. 2 shows the hydrogen generation rate $v s$. the electrode potential, used during various electrolysis experiments. At each potential, the electrolysis was carried out for $60 \mathrm{~min}$. The graph shows the curves for electrolysis of two solutions: a) $0.5 \mathrm{~mol} \mathrm{dm}{ }^{-3}$ and b) $1 \mathrm{~mol} \mathrm{dm}^{-3}$ of $\mathrm{NaBH}_{4}$ both in $3 \mathrm{~mol} \mathrm{dm}^{-3} \mathrm{NaOH}$. The graph also shows the temperature measured at the end of the each experiment. At the open circuit potential, $-0.99 \mathrm{~V} v s$. $\mathrm{Hg} / \mathrm{HgO}$ $(-0.85 \mathrm{~V} v s$. SHE), i.e. at zero current density, the hydrogen generation rates were $1.3 \mathrm{~cm}^{3} \mathrm{~min}^{-1}$ and $0.65 \mathrm{~cm}^{3} \mathrm{~min}^{-1}$ for borohydride concentrations of $0.5 \mathrm{~mol} \mathrm{dm}^{-3}$ and $1 \mathrm{~mol} \mathrm{dm}^{-3}$, respectively. The hydrolysis reaction occurs upon the contact between the sodium borohydride solution and the Pd-Ir electrode surface.

At potentials between $-0.8 \mathrm{~V}$ and $-0.4 \mathrm{~V}$ vs. $\mathrm{Hg} / \mathrm{HgO}(-0.66 \mathrm{~V}$ and $-0.24 \mathrm{~V} v s$. SHE) and a concentration of borohydride of $0.5 \mathrm{~mol} \mathrm{dm}^{-3} \mathrm{NaBH}_{4}$, the hydrogen generation rate diminished almost completely while current densities from $107 \mathrm{~mA} \mathrm{~cm}^{-2}$ to $210 \mathrm{~mA} \mathrm{~cm}^{-2}$ were obtained. At more positive potentials than $-0.2 \mathrm{~V}$ vs. $\mathrm{Hg} / \mathrm{HgO}(-0.06 \mathrm{~V} v$ s. SHE), the gas generation rate slightly started to increase, reaching $0.96 \mathrm{~cm}^{3} \mathrm{~min}^{-1}$, at $0 \mathrm{~V} v s . \mathrm{Hg} / \mathrm{HgO}(0.14 \mathrm{~V} v s$. SHE). In contrast, at $1 \mathrm{~mol} \mathrm{dm}^{-3} \mathrm{NaBH}_{4}$ a lower hydrogen generation rate was measured at the open circuit potential and higher hydrogen generation rate was obtained at all the other measured potentials. This could be related to the Pd oxidation states [3]; at low concentrations of borohydride ions the electrode surface remains in a passive state, the Pd on the surface oxidizes and the borohydride oxidation decreases. Lower current densities and lower hydrogen generation are expected for lower concentrations of borohydride. At high concentrations of borohydride ions, the surface oxide or hydroxide might be reduced by the borohydride and become active again towards the oxidation of borohydride ions [3], also leading to more hydrogen evolution. At $-0.4 \mathrm{~V} v s$. $\mathrm{Hg} / \mathrm{HgO}(-0.24 \mathrm{~V} v s$. SHE), the hydrogen generation rate increased from $0.65 \mathrm{~cm}^{3} \mathrm{~min}^{-1}$ to $1.28 \mathrm{~cm}^{3} \mathrm{~min}^{-1}$, when the concentration of borohydride was increased from $0.5 \mathrm{~mol} \mathrm{dm}^{-3}$ to $1 \mathrm{~mol} \mathrm{dm}^{-3}$, respectively. This agrees with the suggestion of Liu et al., [3] that at palladium electrodes, higher efficiency $\left(6 e^{-}\right)$is obtained using relatively low concentrations of borohydride, whereas for concentrations higher than $1 \mathrm{~mol} \mathrm{dm}^{-3}$ the efficiency decreases $\left(4 e^{-}\right)$.

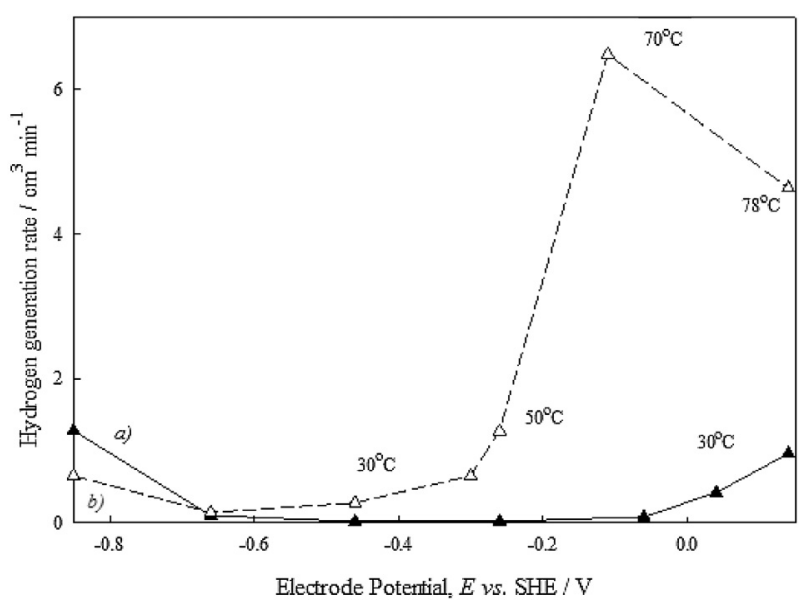

Fig. 2. Gas generation rate $v s$. potential applied at the $\mathrm{Pd} / \mathrm{Ir}$ coated microfibrous carbon electrode $\left(3 \mathrm{~cm}^{2}\right)$. a) $\Delta 1 \mathrm{~mol} \mathrm{dm}{ }^{-3} \mathrm{NaBH}_{4}$ in $\left.3 \mathrm{~mol} \mathrm{dm}^{-3} \mathrm{NaOH}, \mathrm{b}\right) \Delta 0.5 \mathrm{~mol} \mathrm{dm}^{-3}$ $\mathrm{NaBH}_{4}$ in $3 \mathrm{~mol} \mathrm{dm}-3 \mathrm{NaOH}$.
During electrolysis of the electrolyte containing $1 \mathrm{~mol} \mathrm{dm}^{-3}$ $\mathrm{NaBH}_{4}$, the temperature increased from $23{ }^{\circ} \mathrm{C}$ at the beginning of the experiment to 50,70 and $78{ }^{\circ} \mathrm{C}$ at $-0.26,-0.06$ and $0.14 \mathrm{~V} v s$. SHE, respectively. The increase in temperature is due to the exothermic oxidation and hydrolysis reactions that clearly increasing the hydrogen generation rate $[20,21]$ as can be seen in curve a) of Fig. 2. At a $0.5 \mathrm{~mol} \mathrm{dm}{ }^{-3} \mathrm{NaBH}_{4}$ concentration, the temperature increased from $23{ }^{\circ} \mathrm{C}$ to $30{ }^{\circ} \mathrm{C}$ at all the applied potentials. The lower temperature increase during the experiments carried out with $0.5 \mathrm{~mol} \mathrm{dm}^{-3} \mathrm{NaBH}_{4}$ was due to the near absence of exothermic hydrolysis compared to that occurring with $1 \mathrm{~mol} \mathrm{dm}^{-3} \mathrm{NaBH}_{4}$.

Fig. 3 shows a comparison of the hydrogen generation rate vs. current for $1 \mathrm{~mol} \mathrm{dm}^{-3}$ and $0.5 \mathrm{~mol} \mathrm{dm}^{-3} \mathrm{NaBH}_{4}$ in $3 \mathrm{~mol} \mathrm{dm}^{-3}$ $\mathrm{NaOH}$, curves a) and b), respectively during constant potential electrolysis at potential values between $-0.8 \mathrm{~V}$ and $0 \mathrm{~V} v s$. $\mathrm{Hg} / \mathrm{HgO}$ $(-0.66 \mathrm{~V}$ and $0.14 \mathrm{~V}$ vs. SHE). The current density plotted in Fig. 3 was measured during the electrolysis at constant potential and the hydrogen evolution rate at each point corresponds to the potentials of the curves a) and b) in Fig. 2. The figure also compares the results obtained in this work with curves c) and d), reported by Liu et al., [3] using a $\mathrm{Pd} / \mathrm{C}$ electrode having an $8 \mathrm{mg} \mathrm{cm}^{-2}$ catalyst loading and solutions of $0.52 \mathrm{~mol} \mathrm{dm}^{-3}$ in $2 \mathrm{~mol} \mathrm{dm}^{-3} \mathrm{NaOH}$ and $1 \mathrm{~mol} \mathrm{dm}^{-3} \mathrm{NaBH}_{4}$ in $2 \mathrm{~mol} \mathrm{dm}^{-3} \mathrm{NaOH}$, respectively. All the curves show similar trend: hydrogen is generated at zero current, followed by a decrease in the hydrogen generation rate between $100 \mathrm{~mA} \mathrm{~cm}^{-2}$ and $400 \mathrm{~mA} \mathrm{~cm}{ }^{-2}$ and an increase of the hydrogen generation rate at current densities from $400 \mathrm{~mA} \mathrm{~cm}^{-2}$ to higher values. Liu et al., obtained a hydrogen generation rate of $4 \mathrm{~cm}^{3} \mathrm{~min}^{-1}$ at $100 \mathrm{~mA} \mathrm{~cm}{ }^{-2}$ from the solution containing $1 \mathrm{~mol} \mathrm{dm}^{-3} \mathrm{NaBH}_{4}$ in $2 \mathrm{~mol} \mathrm{dm}{ }^{-3} \mathrm{NaOH}$ at a potential of $-0.5 \mathrm{~V} v \mathrm{~s}$. SHE (curve d). At the same current density, a much lower hydrogen generation rate, $0.1 \mathrm{~cm}^{3} \mathrm{~min}^{-1}$, was measured in this work using a $\mathrm{Pd}-\mathrm{Ir}$ alloy and the same concentration of borohydride in $3 \mathrm{~mol} \mathrm{dm}{ }^{-3} \mathrm{NaOH}$. At $300 \mathrm{~mA} \mathrm{~cm}{ }^{-2}$ Liu et al., obtained a hydrogen generation rate of nearly $2.28 \mathrm{~cm}^{3} \mathrm{~min}^{-1}$ and $1.57 \mathrm{~cm}^{3} \mathrm{~min}^{-1}$, for

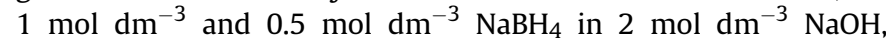
respectively whereas values below $0.5 \mathrm{~cm}^{3} \mathrm{~min}^{-1}$ were obtained using the $\mathrm{Pd} / \mathrm{Ir}$ coated microfibrous carbon electrode at the same current density in this work. The large difference in the hydrogen generation rate obtained by Liu et al., [3] compared to that obtained

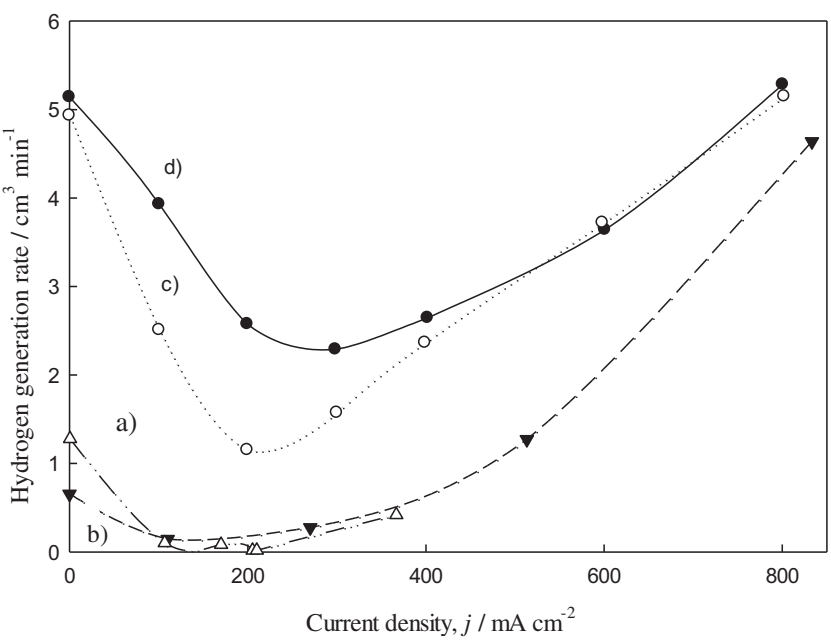

Fig. 3. Gas generation rate vs. current from electrolysis at constant potential: a) $\Delta \mathrm{Pd}$ Ir coated microfibrous carbon electrode using a solution of $0.5 \mathrm{~mol} \mathrm{dm}^{-3} \mathrm{NaBH}_{4}$ in $3 \mathrm{~mol} \mathrm{dm}{ }^{-3} \mathrm{NaOH}$, b) $\Delta \mathrm{Pd} / \mathrm{Ir}$ coated microfibrous carbon electrode and $1 \mathrm{~mol} \mathrm{dm}^{-3}$ $\mathrm{NaBH}_{4}$ in $\left.3 \mathrm{~mol} \mathrm{dm}^{-3} \mathrm{NaOH}, \mathrm{c}\right){ }^{\wedge} 10 \mathrm{wt}$. \% Pd/C and $0.52 \mathrm{~mol} \mathrm{dm}^{-3} \mathrm{NaBH}_{4}$ in $2 \mathrm{~mol} \mathrm{dm}^{-3}$ $\mathrm{NaOH}[3]$, d) 10 wt. \% Pd/C and $1.02 \mathrm{~mol} \mathrm{dm}^{-3} \mathrm{NaBH}_{4}$ in $2 \mathrm{~mol} \mathrm{dm}^{-3} \mathrm{NaOH}$ [3]. 
in this work is attributed to the difference in concentration of $\mathrm{NaOH}$, the presence of Ir and a higher loading of catalyst, which improved the activity by increasing the oxidation of borohydride and decreasing the rate of hydrogen generation.

Fig. 4 shows the apparent number of electrons released per borohydride molecule converted during the electrolysis at constant potential. This value can be calculated according to Equation (4), proposed by Wang et al., [22].

$n_{\mathrm{app}}=\frac{8 I}{I_{G}+I}$

where $I$ is the measured current and $I_{G}$ is the current due to oxidation hydrogen generated during the hydrolysis of borohydride ions (calculated using the Faraday's law and considering a $2 e^{-}$ transfer). For a complete borohydride oxidation, $n_{\mathrm{app}}=8$, there is no hydrogen generation and $I_{G}$ will be zero. According to Fig. 4 , the number of electrons transferred during the electrolysis of $0.5 \mathrm{~mol} \mathrm{dm}^{-3} \mathrm{NaBH}_{4}$ in $3 \mathrm{~mol} \mathrm{dm}{ }^{-3} \mathrm{NaOH}$ was almost 8 for potentials between -0.6 and $-0.4 \mathrm{~V} v s$. $\mathrm{Hg} / \mathrm{HgO}(-0.46$ and $-0.26 \mathrm{~V}$ $v s$. SHE), whereas at $1 \mathrm{~mol} \mathrm{dm}^{-3} \mathrm{NaBH}_{4}$ in $3 \mathrm{~mol} \mathrm{dm}^{-3} \mathrm{NaOH}$ the number of electrons decreased towards more positive potentials from $6 e^{-}$at $-0.8 \mathrm{~V} v s . \mathrm{Hg} / \mathrm{HgO}\left(-0.66 \mathrm{~V} v s\right.$. SHE) to less than $2 e^{-}$ at $-0.2 \mathrm{~V} v s . \mathrm{Hg} / \mathrm{HgO}(-0.06 \mathrm{~V}$ vs. SHE).

The cyclic voltammogram shown in Fig. 5 is for a $0.02 \mathrm{~mol} \mathrm{dm}^{-3}$ $\mathrm{BH}_{4}^{-}$ions concentration at the $\mathrm{Pd}-\mathrm{Ir}$ coated microfibrous carbon electrode $\left(3 \mathrm{~cm}^{2}\right)$ in a three-electrode electrochemical cell. The Figure also shows the $\mathrm{CV}$ of a blank solution $\left(3 \mathrm{~mol} \mathrm{dm}^{-3} \mathrm{NaOH}\right.$ in the absence of borohydride) for comparison. A potential peak, $I$, obtained at $-0.95 \mathrm{~V} v s$. $\mathrm{Hg} / \mathrm{HgO}(-0.81 \mathrm{~V}$ vs. SHE) is attributed to the oxidation of the hydrogen adsorbed on the electrode surface [23]. In the presence of the borohydride ions, the peak is noticeably increased due to the presence of hydrogen formed during the hydrolysis of borohydride at the open circuit potential $(-0.99 \mathrm{~V} v s$. $\mathrm{Hg} / \mathrm{HgO}$ or $-0.85 \mathrm{~V} v s$. SHE). The second peak II, also observed in the blank solution, at $-0.71 \mathrm{~V} v$ s. $\mathrm{Hg} / \mathrm{HgO}(-0.57 \mathrm{~V} v s$. SHE), is surrounded by small shoulders indicating a complex oxidation process of palladium [24]. This peak is attributed to the adsorption of $\mathrm{OH}^{-}$ in the initial stage of the palladium oxide formation and partially overlaps the hydrogen oxidation peak [23]. The small rise III, which emerges from peak II, might be due to the second stage of formation of the palladium (II) oxide layer on the surface of the catalyst

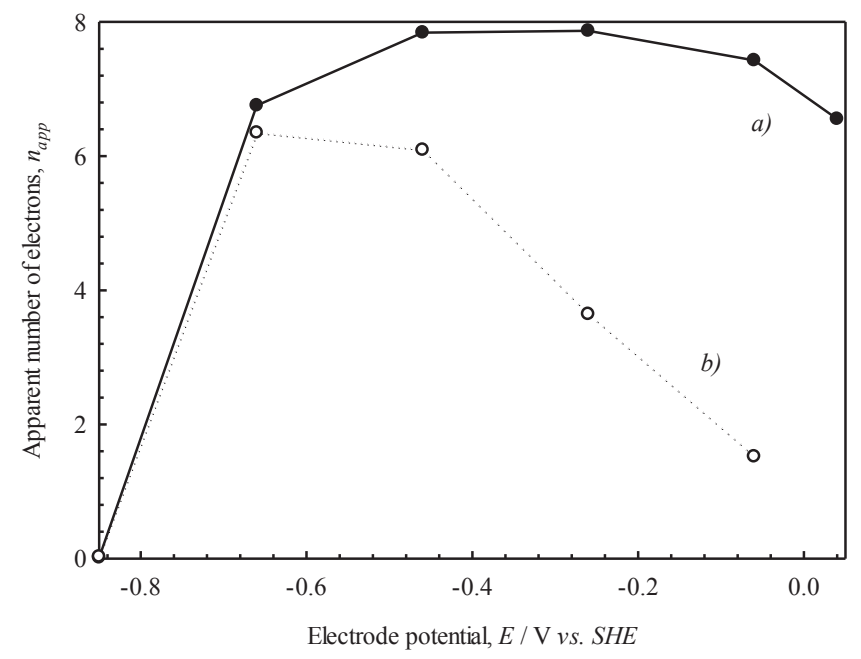

Fig. 4. Apparent number of electrons released during oxidation $v s$. electrode potential from solutions containing: a) $0.5 \mathrm{~mol} \mathrm{dm}{ }^{-3} \mathrm{NaBH}_{4}$ in $3 \mathrm{~mol} \mathrm{dm}^{-3} \mathrm{NaOH}$, b) $1 \mathrm{~mol} \mathrm{dm}^{-3}$ $\mathrm{NaBH}_{4}$ in $3 \mathrm{~mol} \mathrm{dm}^{-3} \mathrm{NaOH}$ at $23^{\circ} \mathrm{C}$ using an Pd-Ir electrode.

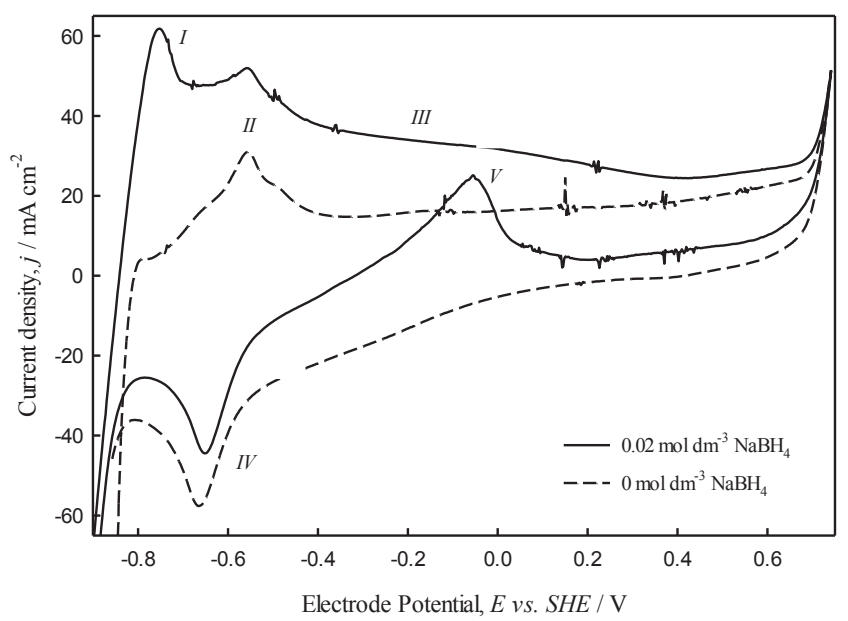

Fig. 5. Cyclic voltammogram at $10 \mathrm{mV} \mathrm{s}^{-1}$ at the $\mathrm{Pd} / \mathrm{Ir}$ coated microfibrous carbon electrode $\left(3 \mathrm{~cm}^{2}\right)$. Solutions containing $0.02 \mathrm{~mol} \mathrm{dm}{ }^{-3} \mathrm{NaBH}_{4}$ in $3 \mathrm{~mol} \mathrm{dm}{ }^{-3} \mathrm{NaOH}$ (black line) and $3 \mathrm{~mol} \mathrm{dm}^{-3} \mathrm{NaOH}$ (broken line), were used.

[25]. In the presence of borohydride, the increase in current densities of peaks II and III is probably due to a mixed oxidation of palladium, borohydride ions and possibly intermediate species formed during borohydride oxidation. The reduction peak $I V$ at $-0.79 \mathrm{~V}$ vs. $\mathrm{Hg} / \mathrm{HgO}(-0.65 \mathrm{~V}$ vs. SHE) on the reverse scan, observed both in the presence of borohydride and in the blank solutions can be attributed to the reduction of $\operatorname{Pd}(\mathrm{II})$ oxide to $\operatorname{Pd}(0)$. On the reverse scan of the borohydride solutions CV an additional oxidation peal $V$ is observed on the reverse scan at $-0.17 \mathrm{~V} v s . \mathrm{Hg} /$ $\mathrm{HgO}(-0.03 \mathrm{~V}$ vs. SHE), which can be attributed to an increased rate of borohydride oxidation on the Ir atoms or on the more active metal formed during the reduction of PdO. Kiran et al., [13] obtained an oxidation peak at $-0.43 \mathrm{~V} v s . \mathrm{Hg} / \mathrm{HgO}(-0.29 \mathrm{~V} v s$. SHE) when they carried out the CV of the $0.1 \mathrm{~mol} \mathrm{dm}^{-3} \mathrm{NaBH}_{4}$ in $1 \mathrm{~mol} \mathrm{dm}^{-3} \mathrm{NaOH}$ using an $\mathrm{Ir} / \mathrm{C}$ anode.

The results shown above suggested that the Pd-Ir catalyst has activity towards borohydride oxidation, resulting in current densities up to $367 \mathrm{~mA} \mathrm{~cm}^{-2}$ during the electrolysis at concentrations of $0.5 \mathrm{~mol} \mathrm{dm}^{-3}$ of $\mathrm{BH}_{4}$. Meanwhile, the hydrogen generation rate was negligible from -0.8 to $0.2 \mathrm{~V} v s$. $\mathrm{Hg} / \mathrm{HgO}(-0.66$ to $-0.06 \mathrm{~V} v s$. SHE). At higher $\mathrm{BH}_{4}^{-}$concentrations, the hydrogen generation increased from $-0.4 \mathrm{~V} v$ s. $\mathrm{Hg} / \mathrm{HgO}(-0.26 \mathrm{~V} v s$. SHE) together with the temperature of the reaction. However, the hydrogen generated at the OCP was significant for both concentrations and might be a problem for the cell performance. The results also showed that the presence of Ir improved the catalytic activity of Pd. In order to corroborate the positive effect of Ir in the Pd-Ir alloy and to obtain a better understanding of the reaction mechanism of borohydride oxidation on Pd-Ir surfaces, DFT calculations of this system are presented in the following section.

\section{Computational methods}

DFT calculations were performed to elucidate the reaction mechanism of borohydride oxidation on $\operatorname{Pd}-\operatorname{Ir}(111)$ surfaces. The effect of the Ir concentration in the Pd-Ir alloy was analyzed by studying the oxidation mechanism on two different bimetallic $\mathrm{Pd}_{2} \mathrm{Ir}_{1}(111)$ and $\mathrm{Pd}_{2} \mathrm{Ir}_{2}(111)$, surfaces. The optimum reaction path was obtained by investigating the elementary surface reaction energies and postulating the lowest energy path taking into account the activation energy for each electron transferred. As a first approximation, the energy of a transferred electron and the ion adsorption energies were made linearly dependent on the 
electrochemical potential and the energy of the adsorbed species was calculated as their free energy $[14,17,26]$.

All calculations were performed using the ab initio total energy and molecular-dynamics Vienna ab initio simulation program (VASP) developed at the Institute for Material Physics at the University of Vienna [27-29]. The projected augmented wave method $[30,31]$ and a plane wave basis set were employed using an energy cut off of $450 \mathrm{eV}$. The generalized gradient approximation (GGA) based on that of Perdew-Wang [32] was used to calculate the exchange and correlation energies. To optimize the structure, a $3 \times 3 \times 1$ Monkhorst-Pack grid [33] was used, followed by a $5 \times 5 \times 1$ grid single-point calculation to give the total energy.

The $\mathrm{Pd}_{2} \mathrm{Ir}_{1}$ and $\mathrm{Pd}_{2} \mathrm{Ir}_{2}$ bimetallic surfaces were modeled using a 3 layer slab and a $3 \times 3$ surface cell and a 3 layer slab with a $4 \times 4$ surface cell, respectively; with the two bottom layers constrained to fcc lattice positions and the two top layers relaxed. A vacuum of $13 \AA$ was inserted between the periodic slabs as a representation of the electrode surface. The borohydride molecule and all possible borohydride oxidation intermediates were optimized on both $\mathrm{Pd}_{2} \mathrm{Ir}_{1}$ and $\mathrm{Pd}_{2} \mathrm{Ir}_{2}$ surfaces.

The adsorption energies of $\mathrm{BH}_{4}^{-}$and borohydride oxidation intermediates were calculated at the optimal adsorption configurations and were corrected for spurious slab-to-slab dipole interactions along the surface normal direction. The reaction energy and activation energy for each step of the oxidation of borohydride were calculated using the lowest energy adsorbed states $[15,16]$. The harmonic vibrational modes were calculated to determine the zero point vibrational (ZPVE) corrections to the total energy of adsorbates. Anderson and Kang [26] and Nørskov et al., [17] have used similar methods, with various perturbations, to study a number of electrocatalytic reactions. The free energies of aqueous phase molecules and ions such as $\mathrm{BH}_{4}^{-}, \mathrm{BO}_{2}^{-}, \mathrm{H}_{2} \mathrm{O}$ and $\mathrm{OH}^{-}$were previously reported by Rostamikia et al., [14], who calculated those values by adding ZPVE, pressure volume (PV) and entropic terms to the isolated gas phase molecule energy $\left(E_{\mathrm{DFT}}\right)$. Experimental solvation free energies and concentration adjustments were included to consider solution conditions, assuming an ideal solution.

The activation energy for each step of the borohydride oxidation reaction on Pd-Ir surfaces was calculated by locating transition states between the lowest energy adsorbed states, presuming that each step follows the minimum energy path $[15,16]$. The transition states of elementary reactions on the surfaces were isolated with the climbing image nudged elastic band method (CI-NEB) [34], which finds saddle points and minimum energy paths between the known reactants and products. Elementary reactions for which barriers were computed include $\mathrm{B}-\mathrm{H}$ dissociation reaction and $\mathrm{B}-\mathrm{OH}$ formation reactions. $\mathrm{A}$ number of equally spaced images (usually 4 images and occasionally
8) between the initial and final states were optimized, with reactiontangent forces and atomic forces meeting optimization criteria and a single harmonic imaginary frequency along the reaction coordinate. The highest energy image corresponds to the transition state, which gives the activation energy of the reaction.

The $\mathrm{B}-\mathrm{H}$ dissociation or $\mathrm{B}-\mathrm{OH}$ formation activation barriers were extrapolated, using a Butler-Volmer formalism and an approach recently developed in the Janik group [16], in order to make them potential dependent. A symmetry factor is used to linearly relate the activation barriers to the equivalent electrochemical reaction [15]:

$\phi_{a_{1}}(E)=\phi_{a_{1}}^{o}-\beta\left(E-E_{o}\right)$

where $\phi_{a_{1}}^{o}$ is the activation barrier for the chemical $\mathrm{B}-\mathrm{H}$ dissociation or $\mathrm{B}-\mathrm{OH}$ formation step, and $\beta$ is the symmetry factor which will be considered 0.5 , assuming a symmetric reaction and in the range of most of the electrochemical reactions [35]. $E_{o}$ is the equilibrium potential that converts the ion involved in the electrochemical step into the equivalent surface species used in locating the transition state $\mathrm{H}^{+}$or $\mathrm{OH}^{-}$converting to $\mathrm{H}^{*}$ or $\mathrm{OH}^{*}$ with electron transfer).

\section{DFT calculation results and discussions}

\subsection{Borohydride ion adsorption over $P d_{2}-I r_{1}(111)$ and $P d_{2}-I r_{2}(111)$}

Fig. 6(a) and (b) shows the optimum configuration for the molecular adsorption of borohydride ions on $\operatorname{Pd}_{2} \operatorname{Ir}_{1}(111)$ and $\mathrm{Pd}_{2} \mathrm{Ir}_{2}$ (111) surfaces, respectively. The $\mathrm{BH}_{4}$ species adsorbs on the $\mathrm{Pd}_{2}-\mathrm{Ir}_{1}(111)$ slab with the boron atom above the Pd-Pd bridge and two $\mathrm{H}$ atoms on Pd atop sites as shown in Fig. 6(a). This was the only stable configuration found for a molecularly adsorbed $\left(\mathrm{BH}_{4}^{*}\right)$ on $\mathrm{Pd}_{2}-\mathrm{Ir}_{1}(111)$. The activation energy for the decomposition of $\mathrm{BH}_{4}^{*}$ to $\mathrm{BH}_{3}^{*}+\mathrm{H}^{*}$ is negligible, dissociative adsorption occurs spontaneously and is thermodynamically favorable $\left(\Delta G_{\mathrm{ads}}<0\right)$, producing $\mathrm{BH}_{3}^{*}+\mathrm{H}^{*}$. The adsorption reaction can be written as:

$\mathrm{BH}_{4}^{-}+* \rightarrow\left(\mathrm{BH}_{3}^{*}+\mathrm{H}^{*}\right)+e^{-}$

where ${ }^{*}$ represents a bare surface. As shown in Fig. 6(b), the borohydride ion is adsorbed on the $\mathrm{Pd}_{2} \mathrm{Ir}_{2}(111)$ surface with the boron atom above the hollow site, two hydrogen atoms on the Pd atoms atop sites and one hydrogen atom on the Ir atom atop site. The adsorption reaction of the borohydride ion on the $\mathrm{Pd}_{2} \mathrm{Ir}_{2}(111)$ surface corresponds to Reaction (7):
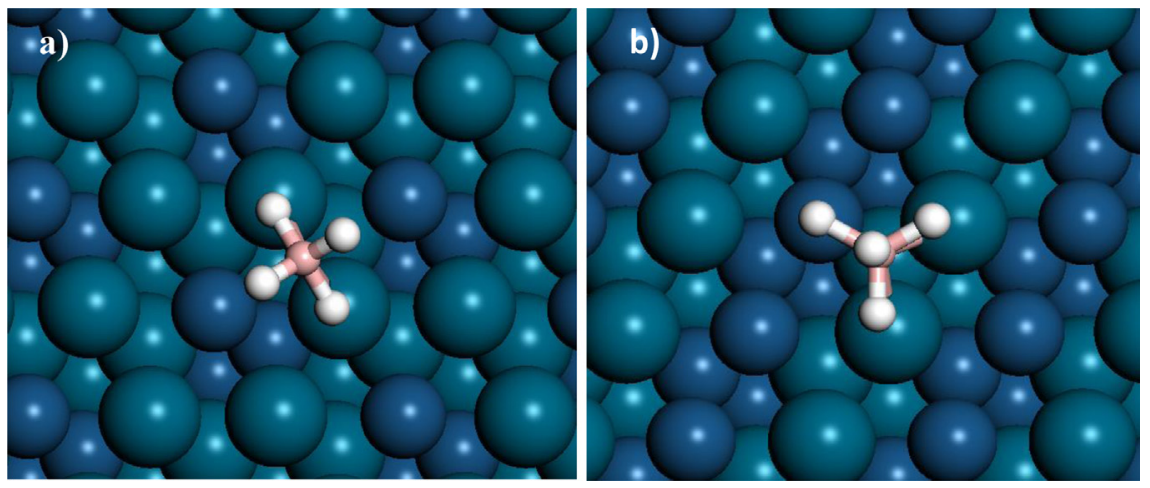

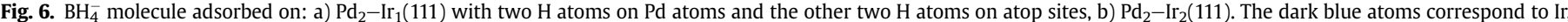

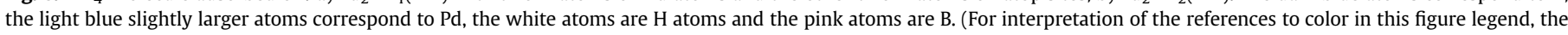
reader is referred to the web version of this article.) 
$\mathrm{BH}_{4(\mathrm{aq})}^{-}+* \rightarrow \mathrm{BH}_{4}^{*}+e^{-}$

The free energy of adsorption of borohydride ions on the $\mathrm{Pd}_{2}-\mathrm{Ir}_{1}(111)$ and $\mathrm{Pd}_{2}-\mathrm{Ir}_{2}(111)$ surfaces can be calculated using Equations (8) and (9):

$\Delta G_{\mathrm{ads}}=G_{\mathrm{BH}_{3}^{*}+\mathrm{H}^{*}}+e E-G_{*}-G_{\mathrm{BH}_{4, \mathrm{aq}}^{-}}$

$\Delta G_{\mathrm{ads}}=G_{\mathrm{BH}_{4}^{*}}+e E-G_{*}-G_{\mathrm{BH}_{4, \mathrm{aq}}^{-}}$

where $G_{\mathrm{BH}_{4 a \mathrm{a}}^{-}}$is the free energy of the borohydride ions in aqueous solution [15], $G *$ is the free energy of the bare surface, $G_{\mathrm{BH}_{3}^{*}+\mathrm{H}^{*}}$ is the free energy of the dissociatively adsorbed borohydride species, $G_{\mathrm{BH}_{4}^{*}}$ is the free energy of the adsorbed molecule, $e^{-}$is the charge of an electron and $E$ is the absolute (vacuum reference) electrode potential. The absolute potential, $E$, can be referred to a standard hydrogen electrode using the equation:

$E_{\mathrm{SHE}}=E-E_{\mathrm{ref}, \mathrm{SHE}}=E-4.6$

where $E_{S H E}$ is the potential $v s$. the standard hydrogen electrode (SHE). Note that $E_{\mathrm{SHE}}$ is what we referred to as $E v s$. SHE in the experimental sections and in Equation (5). The SHE potential has an average value of $4.6 \mathrm{~V}$ referenced to the absolute vacuum [36], and the value of $4.6 \mathrm{~V}$ is consistent with that calculated by Rostamikia et al., [15] using DFT methods.

Fig. 7 plots the adsorption energy of borohydride ions over $\operatorname{Pd}(111), \mathrm{Pd}_{2}-\mathrm{Ir}_{1}(111)$ and $\mathrm{Pd}_{2}-\mathrm{Ir}_{2}(111)$ vs. potential. One adsorbate molecule per nine surface atoms was considered on the $\operatorname{Pd}(111)$ and on the $\mathrm{Pd}_{2} \mathrm{Ir}_{1}$ surfaces and one adsorbate molecule per sixteen surface atoms on the $\mathrm{Pd}_{2} \mathrm{Ir}_{2}$ surface. The adsorption free energy of $\mathrm{BH}_{4}^{-}$over the $\mathrm{Pd}(111), \mathrm{Pd}_{2} \mathrm{Ir}_{1}(111)$ and $\operatorname{Pd}_{2} \mathrm{Ir}_{2}(111)$ surfaces were $-1.77 \mathrm{eV},-1.12 \mathrm{eV}$ and $-0.89 \mathrm{eV}$, respectively at $-0.5 \mathrm{~V} v s$. SHE. The increased fraction of Ir in the bimetallic increases the adsorption energy, making it less exergonic (releases less energy).

The adsorption of borohydride over the $\operatorname{Pd}-\operatorname{Ir}(111)$ surfaces is stronger than that on $\mathrm{Au}(111)$ and weaker than on $\mathrm{Pt}(111)$. The adsorption of borohydride ions at $\mathrm{Au}(111)$ starts being favorable $(\Delta G<0)$ above $0.05 \mathrm{~V}$ vs. SHE [15], whereas at $\mathrm{Pd}-\operatorname{Ir}(111)$ the adsorption of borohydride is favorable at any potential above $-1 \mathrm{~V} v s$. SHE. Pd- $\operatorname{Ir}(111)$ is therefore, active towards this initial oxidation step at more negative potentials than $\mathrm{Au}(111)$. The borohydride adsorption energy on $\mathrm{Pt}(111)$ was $-1.85 \mathrm{eV}$, at $-0.5 \mathrm{~V}$ vs. SHE, which causes dissociation to $\mathrm{BH}^{*}+3 \mathrm{H}^{*}$ [14]. At $\mathrm{Pd}_{2} \mathrm{Ir}_{1}(111)$, the borohydride

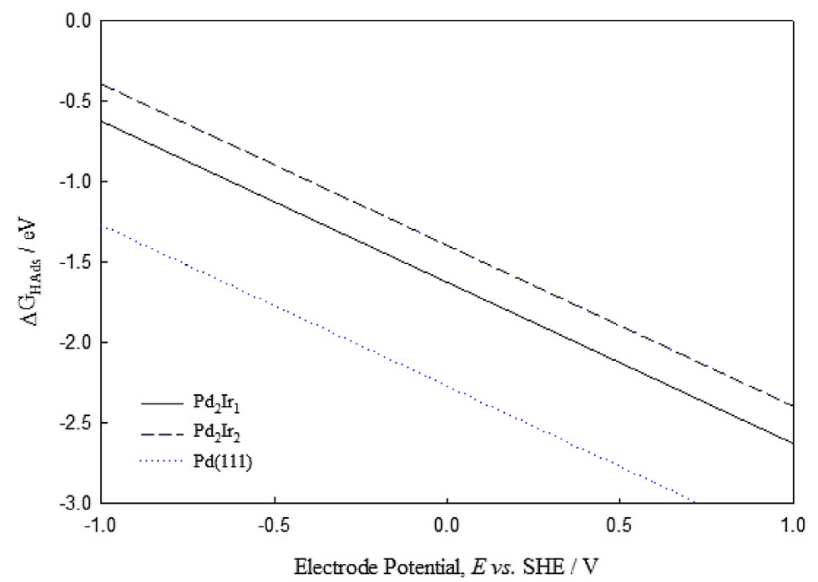

Fig. 7. DFT calculated adsorption free energy of $\mathrm{BH}_{4}^{-}$aq over $\mathrm{Pd}(111), \mathrm{Pd}_{2} \mathrm{Ir}_{1}(111)$ and $\mathrm{Pd}_{2} \mathrm{Ir}_{2}(111)$ using vacuum slab model $\left(T=298 \mathrm{~K},\left[\mathrm{BH}_{4}^{-} \mathrm{aq}\right]=0.03 \mathrm{~mol} \mathrm{dm}^{-3}\right)$. adsorption is less negative than on $\mathrm{Pt}(111)$ and the molecule is spontaneously dehydrated to $\mathrm{BH}_{3}^{*}+\mathrm{H}^{*}$, whereas at $\mathrm{Pd}_{2} \mathrm{Ir}_{2}$ the borohydride molecule was stable and optimized as $\mathrm{BH}_{4}^{*}$. The presence of Ir makes the borohydride adsorption energy more positive and less likely to be dissociative [14,37]. Rostamikia et al., [37] previously suggested that a $\mathrm{BH}_{4}^{-}$adsorption energy intermediate between those at $\mathrm{Au}$ and $\mathrm{Pt}$, with less tendency to dissociate, would allow for a better balance of increased oxidation activity (compared to $\mathrm{Au}$ ) and increased selectivity to direct oxidation over hydrolysis (compared to Pt).

\subsection{Elementary $\mathrm{BH}_{4}^{-}$oxidation energiesat $\mathrm{Pd}_{2} \mathrm{Ir}_{1}(111)$ and $\mathrm{Pd}_{2} \mathrm{Ir}_{2}(111)$ surfaces}

The free energies of the electro-oxidation steps that involve the surface species can be calculated using the following equation:

$R^{*}+x \mathrm{OH}_{\mathrm{aq}}^{-} \rightarrow \mathrm{O}^{*}+y \mathrm{H}_{2} \mathrm{O}+n e^{-}$

where $R^{*}$ is the reactant adsorbed on the surface, $O^{*}$ is the adsorbed oxidized product and $n$ is the number of electrons exchanged. The free energy of Reaction (11) can be calculated as:

$\Delta G_{\mathrm{rXn}}=G_{P^{*}}+y G_{\mathrm{H}_{2} \mathrm{O}_{\mathrm{aq}}}-n e U-G_{R^{*}}-x G_{\mathrm{OH}_{\mathrm{aq}}^{-}}$

The reaction energy diagrams for the borohydride oxidation over $\mathrm{Pd}_{2}-\mathrm{Ir}_{1}(111)$ and $\mathrm{Pd}_{2}-\mathrm{Ir}_{2}(111)$ surfaces were evaluated considering the relative free energies of all adsorbed species with respect to the free energy of the initial aqueous borohydride ion. The relative energy of each species was calculated by combining Equations (7) or (8) and (12), leading to Equation (13) [14].

Relative energy of intermediate species

$$
\begin{aligned}
\mathrm{BO}_{x} \mathrm{H}_{y}^{*}= & G_{\left(\mathrm{BO}_{x} \mathrm{H}_{y}^{*}\right)}+(4-2 x+y) G_{\mathrm{OH}_{\mathrm{aq}}^{-}}-(4+2 x-y) e U \\
& +(4+x-y) G_{\mathrm{H}_{2} \mathrm{O}_{\mathrm{aq}}}-G_{\mathrm{BH}_{4}^{-}}-8 G_{\mathrm{OH}_{\mathrm{aq}}^{-}}
\end{aligned}
$$

where $0<x<2$ and $0<y<4$. The potential dependent activation barriers were also calculated for each electro-oxidation step. As an example, Fig. 8 shows the initial state (a), transition state (b) and final state (c) of the dehydrogenation reaction from $\mathrm{BH}_{3}^{*}$ to $\mathrm{BH}_{2}^{*}+\mathrm{H}^{*}$ on $\mathrm{Pd}_{2} \mathrm{Ir}_{1}$. The activation barrier for this reaction was $0.09 \mathrm{eV}(\mathrm{kJ}$ $\mathrm{mol}^{-1}$ ) at $-0.5 \mathrm{~V} v$ s. SHE. The dissociating $\mathrm{B}-\mathrm{H}$ bond stretches from $1.2 \AA$ in the initial state to $1.35 \AA$ at the transition state. The initial, transition and final states of the same reaction on $\mathrm{Pd}_{2} \mathrm{Ir}_{2}$ are illustrated in Fig. 9(a)-(c), respectively. In this case, at $-0.5 \mathrm{~V}$ vs. SHE, the activation barrier was $0.36 \mathrm{eV}\left(\mathrm{kJ} \mathrm{mol}^{-1}\right)$ and the transition state much closer to the final state, which indicates that this reaction step is more difficult to perform on $\mathrm{Pd}_{2} \mathrm{Ir}_{2}$ than on $\mathrm{Pd}_{2} \mathrm{Ir}_{1}$.

The activation energies for each electro-oxidation step and relative energy of each species are used to evaluate the most likely oxidation reaction mechanism. Fig. 10 shows the relative energies of all possible borohydride oxidation intermediates on $\operatorname{Pd}_{2} \operatorname{Ir}_{1}(111)$ at $-0.5 \mathrm{~V} v s$. SHE. In this diagram, each step to the right is a $1 e^{-}$ oxidation reaction. Steps involving $\mathrm{B}-\mathrm{H}$ dissociation include the conversion of a hydroxyl species to a water molecule, for example the $\mathrm{BH}_{3}^{*}$ to $\mathrm{BH}_{2} \mathrm{O}^{*}$ step is, in complete notation:

$\mathrm{BH}_{3}^{*}+\mathrm{OH}_{\mathrm{aq}}^{-} \rightarrow \mathrm{BH}_{2}^{*}+\mathrm{H}_{2} \mathrm{O}_{\mathrm{aq}}+e^{-}$

For reactions including $\mathrm{B}-\mathrm{OH}$ formation, the complete reaction is, for example:

$\mathrm{BOH}^{*}+\mathrm{OH}_{\mathrm{aq}}^{-} \rightarrow \mathrm{B}(\mathrm{OH})_{2}^{*}+e^{-}$

The most favorable mechanism is highlighted in the diagram with a red straight line. The broken and dotted lines represents 


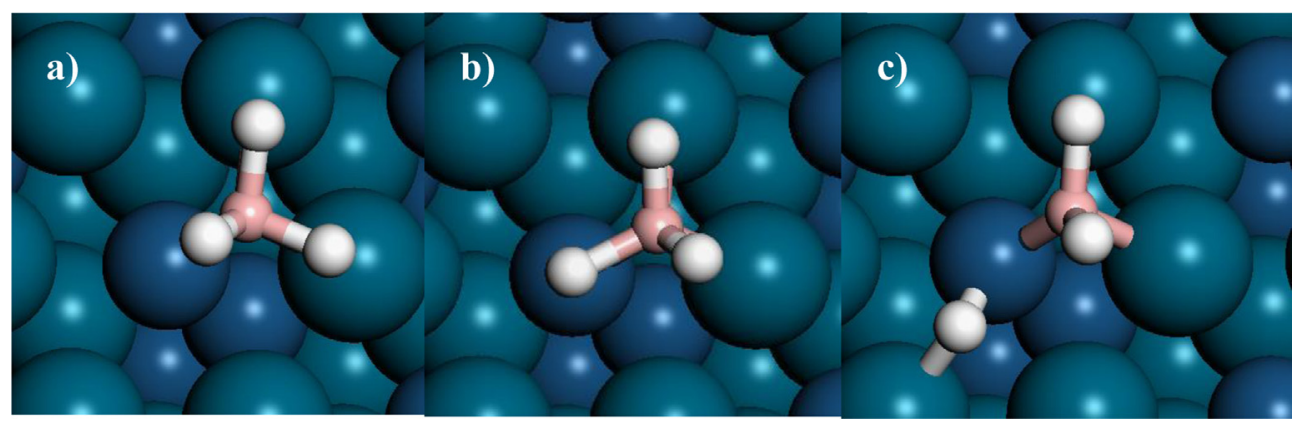

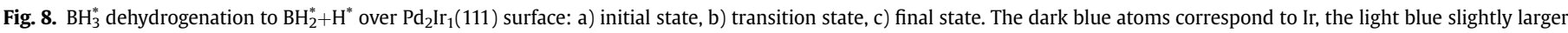

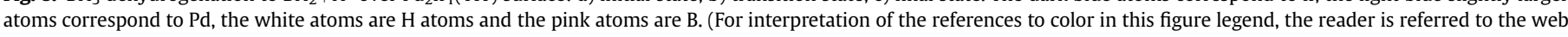
version of this article.)

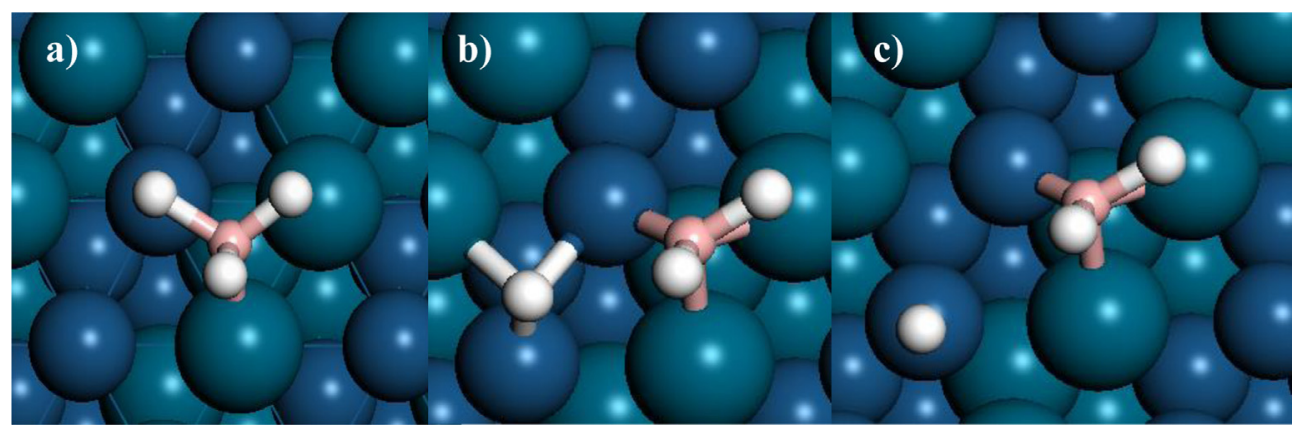

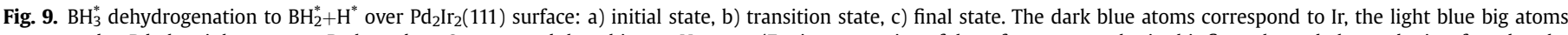

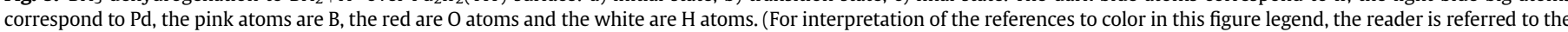
web version of this article.)

the other possible mechanisms calculated with DFT, the most favorable mechanism was determined assuming that the reaction follows the lowest activation energies and the intermediate molecules with the lowest relative energies are involved in the reaction. The values of the activation energy $(\mathrm{eV})$ for each possible step are shown in Fig. 10, between the species. The $8 e^{-}$transfer is favorable since the reaction energy is downhill and each intermediate species has a lower relative energy than the previous one. In general, $\mathrm{B}-\mathrm{H}$ breaking elementary steps are more favorable than $\mathrm{B}-\mathrm{OH}$ bond forming steps. $\mathrm{B}-\mathrm{H}$ dissociation proceeds until the formation of $\mathrm{BH}^{*}$. The first reaction step, from $\mathrm{BH}_{4}^{*}$ to $\mathrm{BH}_{3}^{*}$, is barrier-less and the energy of $\mathrm{BH}_{3}^{*}$ is lower than that of $\mathrm{BH}_{4}^{*}$. The second step considers two possibilities: 1) $\mathrm{BH}_{3}^{*}$ might react with $\mathrm{OH}^{*}$ to form $\mathrm{BH}_{3} \mathrm{OH}^{*}$ or 2) it might dehydrogenate to form $\mathrm{BH}_{2}^{*}$. The latter is more favorable since the reaction product $\mathrm{BH}_{2}^{*}$ has a lower relative energy and the activation barrier for $\mathrm{BH}_{2}^{*}$ formation is $0.09 \mathrm{eV}$, compared with $0.88 \mathrm{eV}$ for $\mathrm{BH}_{3} \mathrm{OH}^{*}$ formation.

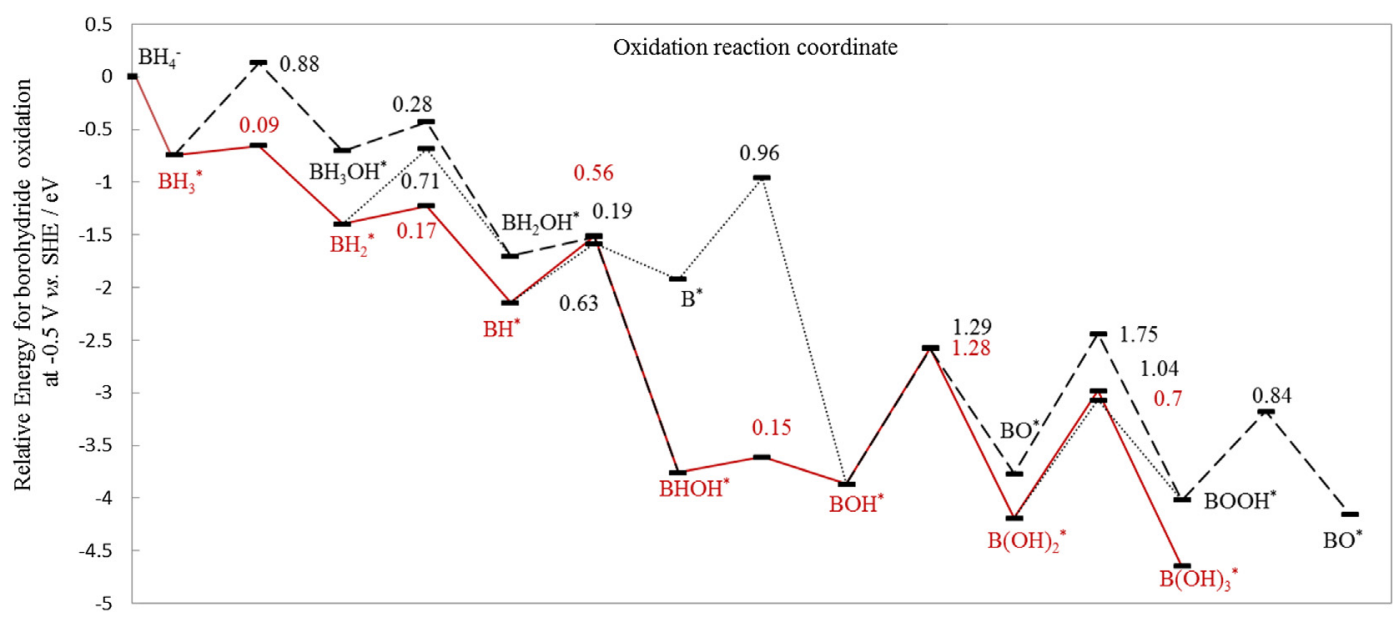

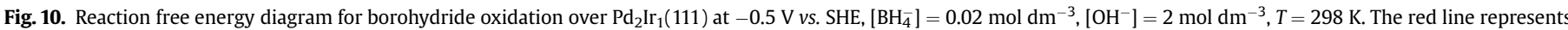

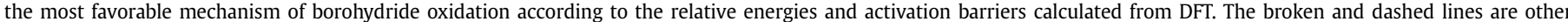

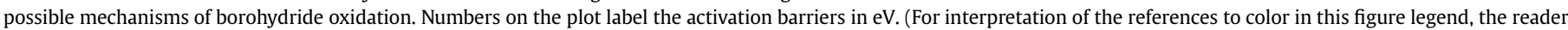
is referred to the web version of this article.) 
Following $\mathrm{B}-\mathrm{H}$ dissociation steps to $\mathrm{BH}^{*}$, reaction with $\mathrm{OH}^{*}$ forms $\mathrm{BHOH}^{*}$, followed by a low energy barrier process forming $\mathrm{BOH}^{*}$. From that point forward, the activation barriers are high enough to conclude that $\mathrm{B}-\mathrm{OH}$ bonds do not form at a substantial rate at room temperature and at $-0.5 \mathrm{~V} v$ s. SHE. Several transition state searches, considering different reaction trajectories were performed to search for paths with lower activation barriers, allowing reaching a final $8 e^{-}$product. However, the lowest activation energies found are reported herein and suggest that $\mathrm{B}-\mathrm{OH}$ formation will be challenging under these conditions, on the single crystal surfaces.

There are two possible interpretations of these results:

1) The reactions of intermediate products with hydroxyl ions limit the overall oxidation reaction. The barriers from $\mathrm{BOH}$ to further oxidation will limit the overall oxidation rate and are possibly too high for the reaction to go forward, leaving $\mathrm{BOH}$ as the final oxidation product. Being a stable species, $\mathrm{BOH}$, might cover the catalyst surface and poison it, reducing the catalyst activity towards the borohydride oxidation. The number of electrons released per $\mathrm{BH}_{4}^{-}$converted on pure $\mathrm{Pd}$ and pure $\mathrm{Ir}$ have been reported to be less than 8 , and thus in a Pd-Ir alloy an 8 electron transfer was not expected. The number of electrons released, according to the mechanism of oxidation highlighted in red in Fig. 10 on $\mathrm{Pd}_{2} \mathrm{Ir}_{1}$, would be 5 terminating with $\mathrm{BOH}$ as the final product.

2) The barriers for $\mathrm{B}-\mathrm{OH}$ forming reactions from the DFT approach used are generally too high due to the lack of surface species solvation in the surface model. The complete oxidation reaction is favorable since all the intermediate products are lower in energy than the previous one, however, the high barriers hinder the reaction to reach the final product to release $8 e^{-}$. Solvation would lower the barrier in three ways: water molecules could more strongly solvate the transition state than initial state, $\mathrm{OH}^{*}$ could be shuttled through a $\mathrm{H}_{2} \mathrm{O}$ molecule $\left(\mathrm{H}\right.$ from $\mathrm{H}_{2} \mathrm{O}$ transfers to $\mathrm{OH}^{*}$ while a $\mathrm{B}-\mathrm{OH}$ bond is formed with the $\mathrm{O}$ of a water molecule), and/or the $E_{o}$ for $\mathrm{OH}^{*}$ formation could be lowered due to solvation of $\mathrm{OH}^{*}$. Nie et al., [18] studied the kinetics of elementary steps in $\mathrm{CO}_{2}$ electro-reduction, finding that for all $\mathrm{O}-\mathrm{H}$ bond formation reactions, water solvation in ion shuttling through $\mathrm{H}_{2} \mathrm{O}$ lowered activation barriers. $\mathrm{C}-\mathrm{H}$ formation reactions did not experience similar stabilization. It is possible that lower activation barriers can be found when considering water molecules close to the borohydride oxidation intermediate steps, leading to easier $\mathrm{B}-\mathrm{OH}$ bond formation and being able to reach the final oxidation product, hydrated metaborate, and releasing $8 e^{-}$. The lack of solvation of $\mathrm{OH}^{*}$ certainly leads to $E_{o}$ being unreasonably high, which raises barriers at $-0.5 \mathrm{~V} v \mathrm{~s}$. SHE. Hydrogen bonding to $\mathrm{OH}^{*}$ is expected to lower $E_{o}$ by approximately $0.4 \mathrm{eV}$, suggesting $\mathrm{B}-\mathrm{OH}$ formation barriers should be lower than those reported herein by at least $0.4 \mathrm{eV}$.

Fig. 11 shows all the reaction free energy diagram for the oxidation of borohydride ions on $\mathrm{Pd}_{2} \mathrm{Ir}_{2}(111)$. The preferable mechanism of reaction is highlighted with red lines. The activation energies of each step are shown in the figure for each possible step. The reaction starts with borohydride adsorption, which was optimized as a stable $\mathrm{BH}_{4}^{*}$. The transition from $\mathrm{BH}_{4}^{*}$ to $\mathrm{BH}_{3}^{*}+\mathrm{H}^{*}$ was barrier-less, meaning that $\mathrm{BH}_{3}^{*}$ formation will spontaneously occur. The next oxidation step following the red line, oxidation of $\mathrm{BH}_{3}^{*}$ had only one possible product, $\mathrm{BH}_{2}^{*}$, since the intermediate molecule $\mathrm{BH}_{3} \mathrm{OH}^{*}$ was unstable and dissociated during the optimization process. An activation barrier of $0.36 \mathrm{eV}$ allows the $\mathrm{BH}_{3}^{*}$ molecule to form $\mathrm{BH}_{2}^{*}$, followed by the formation of $\mathrm{BH}^{*}$, which would tend to overcome $0.45 \mathrm{eV}$ to form a more stable product $\left(\mathrm{BHOH}^{*}\right)$, rather than overcome a slightly higher barrier $0.49 \mathrm{eV}$ to form a less stable $\mathrm{B}^{*}$, that follows the dotted line. From $\mathrm{BHOH}^{*}$ a low barrier of $0.19 \mathrm{eV}$ led to the formation of $\mathrm{BOH}^{*}$. Similar to the mechanism of borohydride oxidation on $\mathrm{Pd}_{2} \operatorname{Ir}_{1}(111)$, from this point the activation barriers to find the final product (metaborate) are higher. However, $\mathrm{BOH}^{*}$ will react with $\mathrm{OH}^{*}$ overcoming $0.55 \mathrm{eV}$ to form $\mathrm{B}(\mathrm{OH})_{2}$. It is possible that at this point the reaction does not go forward due to the high activation barrier between $\mathrm{B}(\mathrm{OH})_{2}^{*}$ and $\mathrm{B}(\mathrm{OH})_{3}^{*}$ and the final product will be $\mathrm{B}(\mathrm{OH})_{2}^{*}$. If the $\mathrm{B}-\mathrm{OH}$ activation barrier from $\mathrm{B}(\mathrm{OH})_{2}^{*}$ was lower, a final product $\mathrm{B}(\mathrm{OH})_{3}$ might react in the solution phase to produce the hydrated borate anion $\left(\mathrm{BO}_{2}\right)[16]$ :

$\mathrm{B}(\mathrm{OH})_{3(\mathrm{aq})}+\mathrm{OH}_{(\mathrm{aq})}^{-} \leftrightarrow \mathrm{B}(\mathrm{OH})_{4(\mathrm{aq})}^{-}$

Then, the reaction mechanism would be finished with the release of $8 e^{-}$. However, further investigations are required to analyze the effect of the solvating conditions, which might decrease the activation barriers in the steps involving $\mathrm{OH}^{-}$. Experimental techniques, such as Raman spectroscopy would also help to demonstrate if the intermediate $\mathrm{B}(\mathrm{OH})_{2}$, is especially stable adsorbed on the electrode surface.

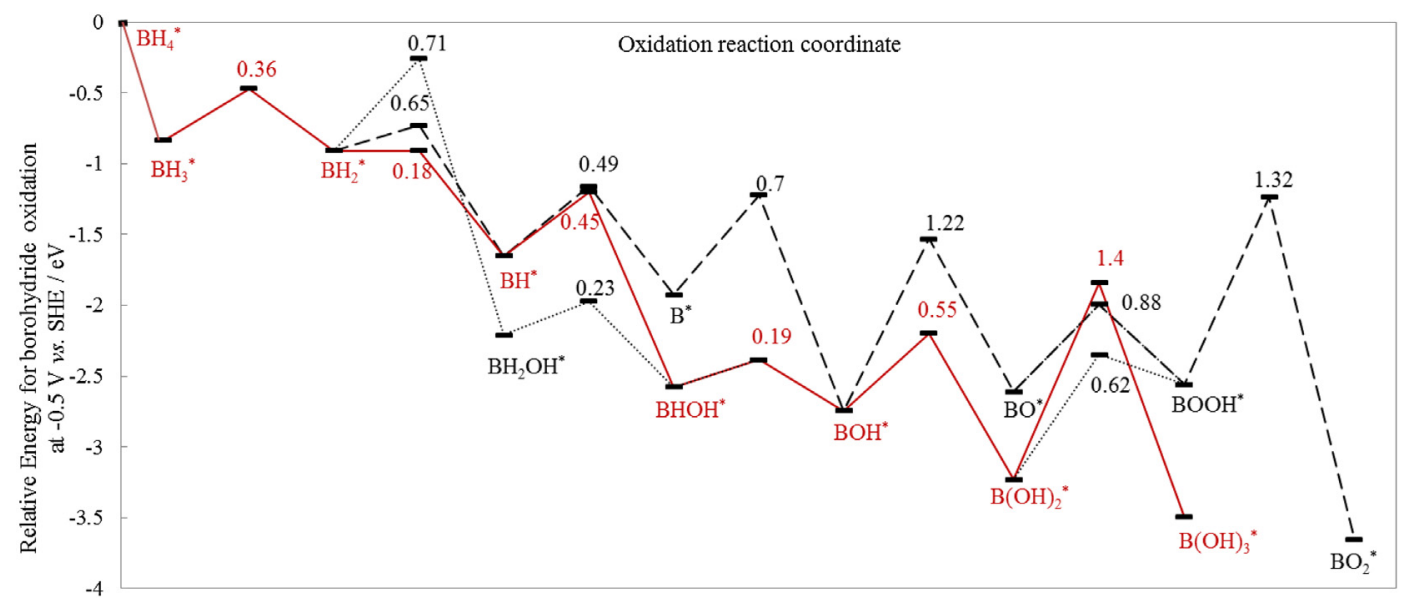

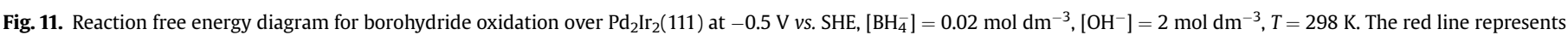

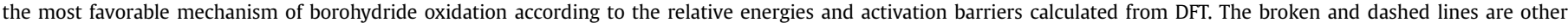

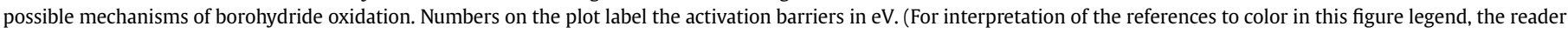
is referred to the web version of this article.) 
Comparing the two diagrams shown in Figs. 10 and 11, the oxidation kinetics are more favorable on $\mathrm{Pd}_{2} \mathrm{I}_{2}$ than on $\mathrm{Pd}_{2} \mathrm{Ir}_{1}$, as the energy barriers for both $\mathrm{B}-\mathrm{H}$ dissociation and $\mathrm{B}-\mathrm{OH}$ formation are generally lower. The $\mathrm{Pd}_{2} \mathrm{Ir}_{2}$ alloy catalyst is slightly more effective towards the borohydride oxidation reaction. The energy barriers from $\mathrm{BOH}^{*}$ to $\mathrm{B}(\mathrm{OH})_{2}^{*}$ is much lower on $\mathrm{Pd}_{2} \mathrm{Ir}_{2}$ than on $\mathrm{Pd}_{2} \mathrm{Ir}_{1}$, which means that at a larger concentration of Ir in the alloy, more complete oxidation may be realized. Other than that, the reaction mechanism on both Pd-Ir surfaces follow the same path, for which molecular structures are summarized in Fig. 12.

\subsection{Competitive borohydride oxidation vs. hydrolysis at the $P d_{2} I r_{1}$ (111) surface}

During the borohydride oxidation on Pd-Ir surfaces, hydrogen atoms from the dehydrogenation processes are adsorbed on the electrode surface. Those hydrogen atoms might either combine with another adsorbed hydrogen atom, forming hydrogen gas (Reaction (17)), or oxidize with a hydroxyl ion to generate water and release one electron (Reaction (18)).
$\mathrm{H}^{*} \rightarrow 1 / 2 \mathrm{H}_{2, \text { gas }}+*$

$\mathrm{H}^{*}+\mathrm{OH}_{\mathrm{aq}}^{-} \rightarrow \mathrm{H}_{2} \mathrm{O}_{\mathrm{aq}}+*+e^{-}$

The free energy of hydrogen oxidation and hydrolysis reactions can be calculated by using Equations (19) and (20), respectively, at $1 \mathrm{~atm}$ and $298 \mathrm{~K}$. A borohydride concentration of $0.02 \mathrm{~mol} \mathrm{dm}^{-3}$ and $3 \mathrm{~mol} \mathrm{dm}^{-3} \mathrm{NaOH}$ was considered to calculate the free energy of $\mathrm{H}^{*}$ adsorption.

$$
\begin{aligned}
& \Delta G_{\text {Evol }}=0.5 G_{\mathrm{H}_{2} \text { gas }}+G_{\text {surf }}-G_{\mathrm{H}^{*}} \\
& \Delta G_{\mathrm{H}_{\text {oxid }}^{*}}=G_{\mathrm{H}_{2} \mathrm{O}}+G_{\text {surf }}-G_{\mathrm{H}^{*}}-G_{\mathrm{OH}^{-}}-e E
\end{aligned}
$$

For an accurate consideration of the competition between hydrogen evolution and hydrogen oxidation, the hydrogen coverage should be considered, as it plays an important role in the hydrogen generation rate. The hydrogen coverage is dictated by the amount of surface hydrogen generated by borohydride

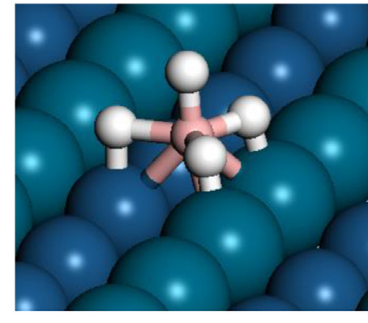

$\mathrm{BH}_{4}{ }^{*}$
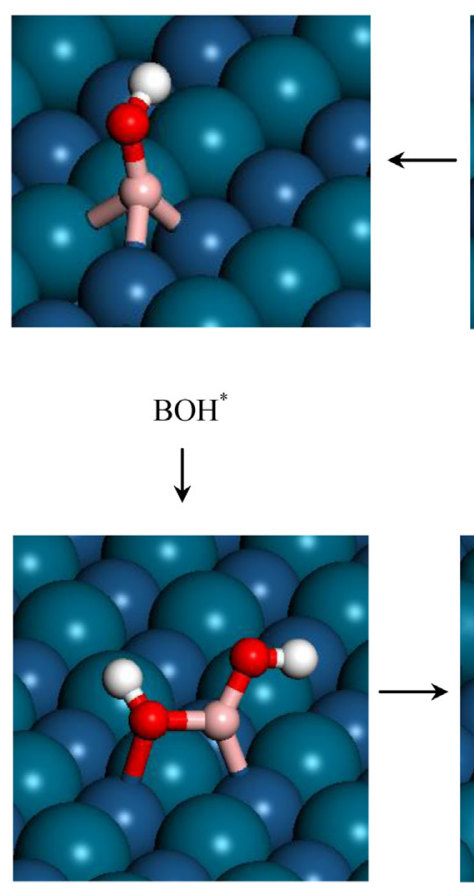

$\mathrm{B}(\mathrm{OH})_{2}{ }^{*}$
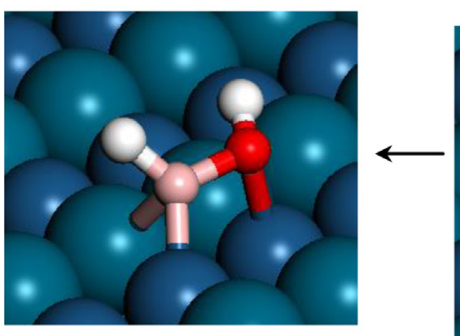

$\mathrm{BHOH}^{*}$

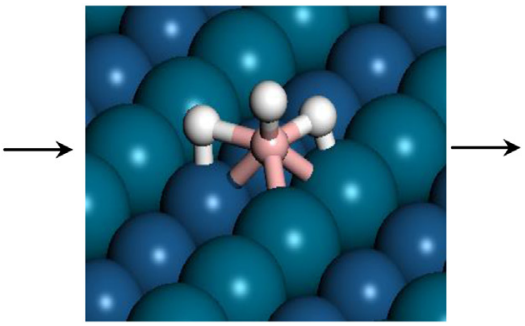

$\mathrm{BH}_{3}{ }^{*}$

$\mathrm{BH}_{2}{ }^{*}$

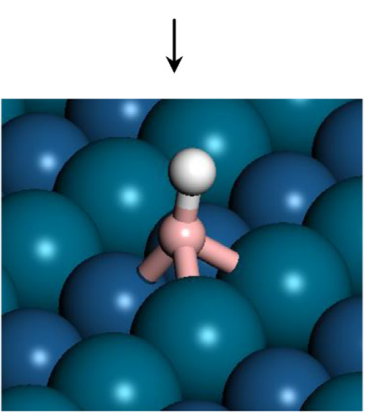

$\mathrm{BH}^{*}$

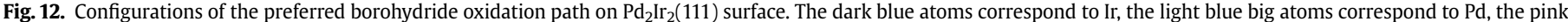

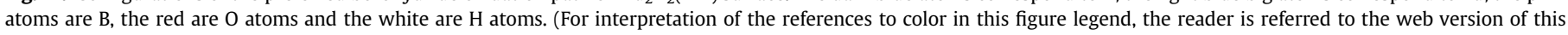
article.) 
dehydrogenation and removed from $\mathrm{H}_{2}$ desorption or $\mathrm{H}^{*}$ oxidation. For a given voltage, higher $\mathrm{H}^{*}$ coverage will be generated for low alkaline solutions (low $\mathrm{pH}$ ) or in solutions at higher temperatures. For a low hydrogen coverage model, one hydrogen atom was optimized on the Pd-Ir surfaces, giving a hydrogen coverage of 1/9 monolayer (ML) atom for the $3 \times 3 \mathrm{Pd}_{2}-\mathrm{Ir}_{1}$ and $1 / 16 \mathrm{ML}$ atom on the $4 \times 4 \mathrm{Pd}_{2}-\mathrm{Ir}_{2}$ surface. For comparison, the hydrogen adsorption was also studied on a $\operatorname{Pd}(111)$ surface. For that purpose, a 4-layer $\operatorname{Pd}(111)$ surface was optimized in a $3 \times 3$ cell. The lowest energy for the optimized hydrogen atom, among all the possible configurations considered, was that when the adsorbed hydrogen was on the fcc configuration at the $\operatorname{Pd}(111)$ surface, on the $\mathrm{Pd}-\mathrm{Ir}$ bridge for $\operatorname{Pd}_{2} \operatorname{Ir}_{1}(111)$ and on the top of the Ir atom for $\operatorname{Pd}_{2} \operatorname{Ir}_{2}(111)$.

The comparison of the free energy of the hydrogen generation reaction (Reaction (18)) and hydrogen oxidation reaction (Reaction (17)) vs. potential for low hydrogen coverage on $\mathrm{Pd}(111), \mathrm{Pd}_{2}-\mathrm{Ir}_{1}$ and $\mathrm{Pd}_{2}-\mathrm{Ir}_{2}$ surfaces is shown in Fig. 13. The free energy of hydrogen evolution did not change with the concentration of Ir in the alloy and has a potential independent positive value of $0.43 \mathrm{eV}$. At low hydrogen coverage, hydrogen evolution is not favorable $(\Delta \mathrm{G}>0)$ for either $\mathrm{Pd}_{2}-\mathrm{Ir}_{1}$ or $\mathrm{Pd}_{2}-\mathrm{Ir}_{2}$ surfaces, at any studied potential. The free energy of oxidation was positive at potentials from -1 to $-0.4 \mathrm{~V}$ vs. $\mathrm{Hg} / \mathrm{HgO}(-0.86$ to $-0.26 \mathrm{~V}$ vs. SHE), suggesting that the reaction will not spontaneously occur if the $\mathrm{H}^{*}$ coverage is low at those potentials. At more positive potentials than $-0.4 \mathrm{~V} v s$. $\mathrm{Hg} / \mathrm{HgO}\left(-0.26 \mathrm{~V}\right.$ vs. SHE), the $\mathrm{H}^{*}$ oxidation is favorable $(\Delta G<0)$. At the $\operatorname{Pd}(111)$ surface, both the free energy of hydrogen evolution and oxidation were more positive than on the Pd-Ir surfaces. Therefore, at low $\mathrm{H}^{*}$ coverage and at any studied potential, the hydrogen oxidation and evolution are more favorable on the bimetallic surfaces than on pure $\operatorname{Pd}(111)$, due to weaker $\mathrm{H}$ binding to the surface. The binding energy ( $\mathrm{BE}$ ) of the $\mathrm{H}$ to the $\mathrm{Pd}(111), \mathrm{Pd}_{2} \mathrm{Ir}_{1}(111)$ and $\mathrm{Pd}_{2} \mathrm{Ir}_{2}(111)$ surfaces, which can be calculated using Equation (21) [14], are $-0.61 \mathrm{eV},-0.43 \mathrm{eV}$ and $-0.41 \mathrm{eV}$, respectively.

$\mathrm{BE}=E_{\mathrm{DFT}, \mathrm{H}^{*}}-E_{*}-E_{\mathrm{H}}$

Weaker $\mathrm{H}$ binding on the bimetallic surfaces might lead to lower $\mathrm{H}$ coverage, and therefore a faster oxidation reaction rate relative to evolution, as the oxidation (rate $\alpha \Theta_{\mathrm{H}}$ ) and evolution rates (rate $\alpha$ $\Theta_{\mathrm{H}}^{2}$ ) directly depend on the hydrogen coverage.

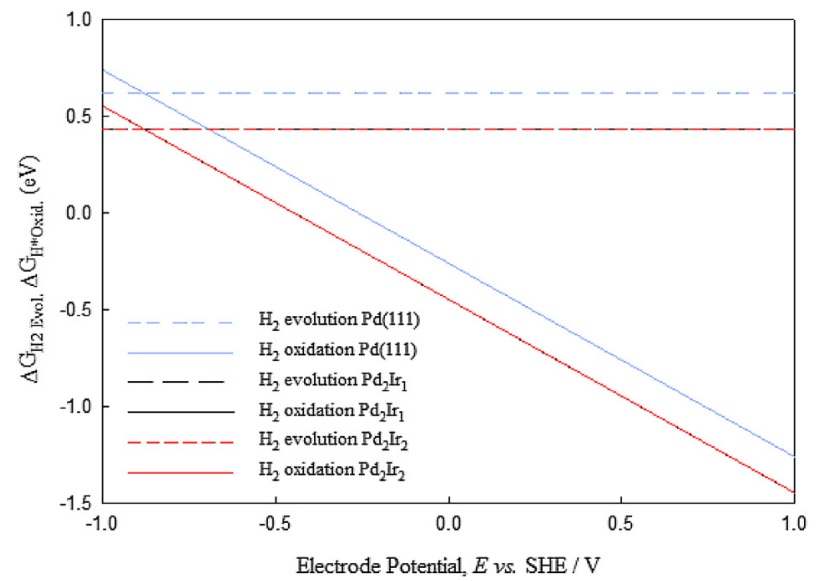

Fig. 13. Reaction free energies for $\mathrm{H}^{*}$ oxidation (straight line) and evolution (dash line) of $\mathrm{H}_{2}$ gas as a function of potential for low hydrogen coverage $1 / 9 \mathrm{ML} \mathrm{H}^{*}$ on $\mathrm{Pd}_{2} \mathrm{Ir}_{1}(111)$ surface (black lines), $1 / 16 \mathrm{ML} \mathrm{H}^{*}$ on $\mathrm{Pd}_{2} \mathrm{Ir}_{2}(111)$ surface (red lines) and $1 / 9 \mathrm{ML} \mathrm{H}^{*}$ on $\operatorname{Pd}(111)$ surface (blue lines). The $\mathrm{Pd}_{2} \mathrm{Ir}_{1}(111)$ and the $\mathrm{Pd}_{2} \mathrm{Ir}_{2}(111)$ lines overlay each other. (For interpretation of the references to color in this figure legend, the reader is referred to the web version of this article.)
At higher hydrogen coverage, the free energy of evolution and oxidation are expected to become more exergonic, as increasing the number of hydrogen atoms on the surface destabilizes $\mathrm{H}^{*}$. At high hydrogen coverage, 9 hydrogen atoms were optimized on the $3 \times 3$ cell, to give hydrogen coverage of $1 \mathrm{ML}$ atom for the $\mathrm{Pd}_{2}-\mathrm{Ir}_{1}$ surface. For the $\mathrm{Pd}_{2}-\mathrm{Ir}_{2}$ surface, 16 hydrogen atoms were optimized on the $4 \times 4$ cell giving $1 \mathrm{ML}$ coverage. The large number of possible configurations of the 9 hydrogen atoms on the surface decreases the likelihood of locating a global optimum structure. Moreover, the data obtained suffers from model imperfections, as the bimetallic structure disrupts the symmetry and can lead to effects in $\mathrm{H}$ binding that are not practical in a typical experimental alloy electrode, which is probably less ordered. The difference in cell size between $\mathrm{Pd}_{2} \mathrm{Ir}_{1}$ and $\mathrm{Pd}_{2} \mathrm{Ir}_{2}$ also allows for differences in the surface reorganization allowed. However, these calculations can provide an orientation of the hydrogen behavior at high coverage on the $\mathrm{Pd}-\mathrm{Ir}$ and Pd surfaces.

At the pure Pd electrode, the optimized structure had the $9 \mathrm{H}$ atoms in fcc sites. In contrary, on the $\mathrm{Pd}_{2} \mathrm{Ir}_{1}$ surface, the $9 \mathrm{H}$ atoms changed location during the optimization process from the symmetric hollow sites to interact with the Ir atoms. At the $\mathrm{Pd}_{2} \mathrm{Ir}_{2}$ surface, the 16 hydrogen atoms were initially located on Pd and Ir atop sites, but the hydrogen atoms tend to move towards the Ir instead of to the Pd atoms. The $\mathrm{Pd}_{2} \mathrm{Ir}_{2}$ surface to offers enough Ir atoms such that all $\mathrm{H}$ can move from their symmetric hollow sites towards Ir atoms, making stripes of $\mathrm{H}$ atoms. These Ir stripes, which form a regular pattern, might provide a greater stabilization to the $\mathrm{H}$ high coverage and the strong $\mathrm{H}$ binding could hurt the selectivity of the catalyst towards the oxidation. However, these calculations consider an ideal material configuration consisting of Pd layers followed by Ir layers that are difficult to achieve experimentally.

The results showed more negative and thus more favorable free energies of hydrogen oxidation and hydrogen evolution than those obtained at low hydrogen coverage, as was expected. At high hydrogen coverage on the $\operatorname{Pd}_{2} \mathrm{Ir}_{1}$ surface, the free energy of the hydrogen evolution was favorable (approximately $-0.73 \mathrm{eV}$ ). That value was $0.7 \mathrm{eV}$ more negative on $\mathrm{Pd}_{2} \mathrm{Ir}_{2}$ suggesting that the presence of Ir makes more favorable the hydrogen generation. The crossing point at which oxidation competes with evolution does not vary for the studied materials ( $\mathrm{Pd}, \mathrm{Pd}_{2} \mathrm{Ir}_{1}$ and $\mathrm{Pd}_{2} \mathrm{Ir}_{2}$ ). The two lines in Fig. 13, corresponding to free energy of hydrogen evolution and oxidation, intercept at approximately $-1 \mathrm{~V} v s . \mathrm{Hg} / \mathrm{HgO}(-0.86 \mathrm{~V}$ $v s$. SHE), and the free energy of oxidation is lower than the free energy of hydrogen evolution at more positive potentials. That suggests that at more positive potentials than $-1 \mathrm{~V}$ vs. $\mathrm{Hg} / \mathrm{HgO}$ $(-0.86 \mathrm{~V} v s$. SHE), the hydrogen atom adsorbed on the surface would oxidize rather than evolve as hydrogen bubbles. At more negatives potentials than $-1 \mathrm{~V}$ vs. $\mathrm{Hg} / \mathrm{HgO}(-0.86 \mathrm{~V} v s$. SHE), the hydrogen evolution is more favorable than the oxidation and thus, hydrogen bubbles would evolve. This agrees with the experimental results showed in Fig. 2, as hydrogen generation was observed at the open circuit potential $(-0.99 \mathrm{~V} v s$. $\mathrm{Hg} / \mathrm{HgO}$ or $-0.85 \mathrm{~V} v \mathrm{~s}$. SHE) and at more positive potentials the hydrogen generation substantially decreased. It can be concluded that the presence of Ir in the bimetallic alloy decreases the free energy of oxidation, making the $\mathrm{Pd}_{2} \mathrm{Ir}_{2}$ surface more favorable for the borohydride oxidation at all potentials, compared to the $\mathrm{Pd}_{2} \mathrm{Ir}_{1}$.

\section{Summary and conclusions}

The catalytic activity of the Pd-Ir alloy for the borohydride oxidation and its hydrolysis was experimentally and computationally analyzed. The Pd-Ir coated microfibrous carbon supported on a titanium plate electrode showed catalytic activity towards the borohydride oxidation, obtaining current densities from 100 to 
$200 \mathrm{~mA} \mathrm{~cm}^{-2}$, when a solution containing $0.5 \mathrm{~mol} \mathrm{dm}^{-3} \mathrm{NaBH}_{4}$ in $3 \mathrm{~mol} \mathrm{dm}{ }^{-3} \mathrm{NaOH}$ and a $3 \mathrm{~cm}^{2}$ electrode geometric surface area, were used. At the same time, the hydrogen generation rate was minimized to less than $0.1 \mathrm{dm}^{3} \mathrm{~min}^{-1}$. For that reason, Pd-Ir seems to be a promising material for the borohydride oxidation. However, there are some drawbacks that need to be addressed before the Pd-Ir alloy can be used in a DBFC, such as the high cost and the spontaneous hydrogen generation at open circuit potential $(-0.99 \mathrm{~V} v$ s. $\mathrm{Hg} / \mathrm{HgO},-0.85 \mathrm{~V} v$ s. SHE). Further experiments need to be carried out in a complete cell, in order to test the catalyst and estimate the importance of the inconvenience of the hydrogen generation at the OCP.

DFT studies were carried out at the $\mathrm{Pd}_{2} \mathrm{Ir}_{1}$ and $\mathrm{Pd}_{2} \mathrm{Ir}_{2}$ surfaces in order to analyze the mechanism of the borohydride oxidation reaction and evaluate the effect of the Ir concentration. The results showed that in the presence of Ir, the Gibbs free energy of $\mathrm{BH}_{4}$ adsorption is lower than that on pure Pd, at all potentials, which suggests that the oxidation reaction starts at more negative potentials on the alloy than on pure Pd. DFT studies also showed that at high hydrogen coverage and $-1 \mathrm{~V} v s . \mathrm{Hg} / \mathrm{HgO}(-0.86 \mathrm{~V} v s$. SHE), there is hydrogen generation but at more positive potentials the oxidation of borohydride is more favorable than the hydrolysis. These results agree with experimental observation, the reaction mechanism on both Pd-Ir surfaces followed the same path, showing a favorable 8 electron transfer. However, the activation energies became too high in the last elementary steps, which involve $\mathrm{B}-\mathrm{OH}$ binding. The activation barriers were generally lower on $\mathrm{Pd}_{2} \mathrm{Ir}_{2}$ than on $\mathrm{Pd}_{2} \mathrm{Ir}_{1}$, with the reaction mechanism more favorable on the former. From $\mathrm{BOH}$ at $\mathrm{Pd}_{2} \mathrm{Ir}_{1}$ and $\mathrm{BOHOH}$ at $\mathrm{Pd}_{2} \mathrm{Ir}_{2}$, the activation barriers became too high and it is possible that the reaction does not continue any further. In that case, the number of electrons released would be 5 and 6 , at $\mathrm{Pd}_{2} \mathrm{Ir}_{1}$ and $\mathrm{Pd}_{2} \mathrm{Ir}_{2}$, respectively. Those intermediate species, $\mathrm{BOH}$ at $\mathrm{Pd}_{2} \mathrm{Ir}_{1}$ and $\mathrm{BOHOH}$ at $\mathrm{Pd}_{2} \mathrm{Ir}_{2}$, might cover the catalyst surfaces, being a poison and reducing the catalytic activity of the electrodes towards the borohydride oxidation.

Although the complete oxidation reaction seems to be favorable according to the relative energy diagram, it is possible that the DFT approach used for the calculation of the activation barriers of the $\mathrm{B}-\mathrm{OH}$ forming reactions overestimates energy barriers, due to the lack of consideration of solvation. Computational models that include the role of water, by adding two $\mathrm{H}_{2} \mathrm{O}$ molecules next to the $\mathrm{BH}_{4}$ molecule, can be utilized to decrease the activation barriers corresponding to $\mathrm{B}-\mathrm{OH}$ bond formation and obtain the final oxidation product, metaborate, and release $8 e^{-}$.

\section{References}

[1] C. Ponce de Leon, F.C. Walsh, D. Pletcher, D.J. Browning, J.B. Lakeman, J. Power Sources 155 (2006) 172-181.

[2] I. Merino-Jiménez, C. Ponce de León, A. Shah, F.C. Walsh, J. Power Sources 219 (2012) 339-357.

[3] B.H. Liu, Z.P. Li, S. Suda, Electrochim. Acta 49 (2004) 3097-3105.

[4] M.V. Mirkin, H. Yang, A.J. Bard, J. Electrochem. Soc. 139 (1992) 2212-2217.

[5] S.C. Amendola, P. Onnerud, M.T. Kelly, P.J. Petillo, S.L. Sharp-Goldman, M. Binder, J. Power Sources 84 (1999) 130-133.

[6] B.M. Concha, M. Chatenet, E.A. Ticianelli, F.H. Lima, R.D. Lima, 216 ECS Meeting Abstracts 11th International Symposium on Solid Oxide Fuel Cells, vol. 902. Vienna, Austria, 2009, p. 368.

[7] M. Chatenet, F.H.B. Lima, E.A. Ticianelli, J. Electrochem. Soc. 157 (2010) B697-B704.

[8] E. Gyenge, M. Atwan, D. Northwood, J. Electrochem. Soc. 153 (2006) A150-A158.

[9] J. Ma, N.A. Choudhury, Y. Sahai, Renewable Sustainable Energy Rev. 14 (2010) 183-199.

[10] D.A. Finkelstein, N.D. Mota, J.L. Cohen, H.c.D. Abruña, J. Phys. Chem. C 113 (2009) 19700-19712

[11] G.H. Miley, N. Luo, J. Mather, R. Burton, G. Hawkins, L. Gu, E. Byrd, R. Gimlin, P.J. Shrestha, G. Benavides, J. Laystrom, D. Carroll, J. Power Sources 165 (2007) 509-516.

[12] J.Q. Yang, B.H. Liu, S. Wu, J. Power Sources 194 (2009) 824-829.

[13] V. Kiran, T. Ravikumar, N.T. Kalyanasundaram, S. Krishnakumar, A.K. Shukla, S. Sampath, J. Electrochem. Soc. 157 (2010) B1201-B1208.

[14] G. Rostamikia, M.J. Janik, Electrochim. Acta 55 (2010) 1175-1183.

[15] G. Rostamikia, M.J. Janik, J. Electrochem. Soc. 156 (2009) B86-B92.

[16] G. Rostamikia, A.J. Mendoza, M.A. Hickner, M.J. Janik, J. Power Sources 196 (2011) 9228-9237.

[17] J.K. Nørskov, J. Rossmeisl, A. Logadottir, L. Lindqvist, J.R. Kitchin, T. Bligaard, H. Jónsson, J. Phys. Chem. B 108 (2004) 17886-17892.

[18] X. Nie, M.R. Esopi, M.J. Janik, A. Asthagiri, Angew. Chem. Int. Ed. 52 (2013) 2459-2462.

[19] C.J. Patrissi, R.R. Bessette, Y.K. Kim, C.R. Schumacher, J. Electrochem. Soc. 155 (2008) B558-B562.

[20] C. Celik, F.G. Boyaci San, H.I. Sarac, J. Power Sources 185 (2008) 197-201.

[21] B.H. Liu, Z.P. Li, S. Suda, J. Electrochem. Soc. 150 (2003) A398-A402.

[22] K. Wang, J. Lu, L. Zhuang, Catal. Today 170 (2011) 99-109.

[23] A.E. Bolzan, J. Electroanal. Chem. 380 (1995) 127-138.

[24] G. Denuault, C. Milhano, D. Pletcher, Phys. Chem. Chem. Phys. 7 (2005) $3545-3551$.

[25] Z.X. Liang, T.S. Zhao, J.B. Xu, L.D. Zhu, Electrochim. Acta 54 (2009) 2203-2208.

[26] A.B. Anderson, D.B. Kang, J. Phys. Chem. A 102 (1998) 5993-5996.

[27] G. Kresse, J. Furthmüller, Comput. Mater. Sci. 6 (1996) 15-50.

[28] G. Kresse, J. Furthmüller, Phys. Rev. B 54 (1996) 11169.

[29] G. Kresse, J. Hafner, Phys. Rev. B 47 (1993) 558.

[30] A.U. Nilekar, M. Mavrikakis, Surf. Sci. 602 (2008) L89-L94.

[31] Y. Xu, A.V. Ruban, M. Mavrikakis, J. Am. Chem. Soc. 126 (2004) 4717-4725.

[32] J. Greeley, T.F. Jaramillo, J. Bonde, I. Chorkendorff, J.K. Nørskov, Nature 5 (2006) 909-913.

[33] H.J. Monkhorst, J.D. Pack, Phys. Rev. B 13 (1976) 5188-5192.

[34] G. Helkeman, B.P. Uberuaga, H. Jonsson, J. Chem. Phys. 113 (2000) 9901.

[35] A.J. Bard, L.R. Faulkner, Electrochemical Methods Fundamentals and Applications, second ed., John Wiley and Sons, Inc., 2001.

[36] D. Tsiplakides, C.G. Vayenas, Solid State Ionics 152-153 (2002) 625-639.

[37] G. Rostamikia, R.J. Patel, I. Merino-Jimenez, M. Hickner, M.J. Janik, in preparation. 